\title{
Communicating the Family Firm Brand Antecedents and Performance Effects
}

Beck, Susanne; Prügl, Reinhard; Walter, Katharina

Document Version

Accepted author manuscript

Published in:

European Management Journal

DOI:

10.1016/j.emj.2019.04.008

Publication date:

2020

License

CC BY-NC-ND

Citation for published version (APA):

Beck, S., Prügl, R., \& Walter, K. (2020). Communicating the Family Firm Brand: Antecedents and Performance Effects. European Management Journal, 38(1), 95-107. https://doi.org/10.1016/j.emj.2019.04.008

Link to publication in CBS Research Portal

\section{General rights}

Copyright and moral rights for the publications made accessible in the public portal are retained by the authors and/or other copyright owners and it is a condition of accessing publications that users recognise and abide by the legal requirements associated with these rights.

Take down policy

If you believe that this document breaches copyright please contact us (research.lib@cbs.dk) providing details, and we will remove access to the work immediately and investigate your claim. 


\title{
Communicating the Family Firm Brand: Antecedents and Performance Effects
}

\section{Susanne Beck, Reinhard Prügl, and Katharina Walter}

Journal article (Accepted manuscript*)

\section{Please cite this article as:}

Beck, S., Prügl, R., \& Walter, K. (2019). Communicating the Family Firm Brand: Antecedents and Performance Effects. European Management Journa/. https://doi.org/10.1016/j.emj.2019.04.008

\author{
DOl: https://doi.org/10.1016/j.emj.2019.04.008
}

* This version of the article has been accepted for publication and undergone full peer review but has not been through the copyediting, typesetting, pagination and proofreading process, which may lead to differences between this version and the publisher's final version AKA Version of Record.

Uploaded to CBS Research Portal: August 2019

(C) 2019. This manuscript version is made available under the CC-BY-NC-ND 4.0 license http://creativecommons.org/licenses/by-nc-nd/4.0/ 


\author{
Susanne Beck \\ Department of Innovation and Organizational Economics \\ Copenhagen Business School, Copenhagen, Denmark \\ Ludwig Boltzmann Gesellschaft \\ Open Innovation in Science Center (LBG OIS Center) \\ Nußdorferstr. 64 \\ 1090 Vienna \\ Austria \\ Friedrichshafen Institute of Family Entrepreneurship | FIF \\ FIF@Zeppelin University, Lake Constance, Germany \\ Reinhard Prügl \\ Friedrichshafen Institute of Family Entrepreneurship | FIF \\ FIF@Zeppelin University, Lake Constance, Germany \\ e-mail: reinhard.pruegl@zu.de \\ Katharina Walter \\ Friedrichshafen Institute of Family Entrepreneurship | FIF \\ FIF@Zeppelin University, Lake Constance, Germany
}

\begin{abstract}
Building a family business brand allows family firms to leverage a valuable idiosyncratic resource: their family nature ("we are a family business"). But this is only possible if the owning family decides to reveal a family firm image ("we want others to know that we are a family business"). Family firms largely vary in that regard: While some family firms do strongly emphasize a family firm image, others do so at a lower level or not at all. Accordingly, this study applies mixed methods exploring and testing antecedents of the degree of revealing the family nature of the business in the context of German Mittelstand firms. In study 1 we develop hypotheses for the antecedents of that important managerial decision based on the family business literature as well as interviews with eleven family firm executives. In study 2 we collect data $(\mathrm{N}=196)$ from family firm CEOs to test our hypotheses. Furthermore, we provide supplementary analysis exploring performance consequences of the degree of revealing. Results show that out of eleven antecedents emerging from study 1, seven do significantly impact the degree of applying a family business branding strategy. Insights from our supplemental analysis suggest that the degree of communication of a family firm brand is positively related to firm and brand performance.
\end{abstract}

Keywords: family business brand, family firm image, branding strategy, mixed methods design

Acknowledgements: We hereby acknowledge important comments on earlier versions of this manuscript from conference participants and members of the SIG FBR at EURAM, in particular Claudia Binz Astrachan, Joe Astrachan, Isabel Botero, and Andrea Calabró. 


\section{Communicating the family firm brand: antecedents and performance effects}

Abstract:

Building a family business brand allows family firms to leverage a valuable idiosyncratic resource: their family nature (we are a family business). But, this is only possible if the owning family decides to reveal a family firm image (we want others to know that we are a family business). Family firms largely vary in that regard: While some family firms do strongly emphasize a family firm image, others do so at a lower level or not at all. Accordingly, this study applies mixed methods exploring and testing antecedents of the degree of revealing the family nature of the business in the context of German Mittelstand firms. In study 1, we develop hypotheses for the antecedents of that important managerial decision based on the family business literature as well as interviews with family firm executives. In study 2, we collect data $(\mathrm{N}=196)$ from family firm CEOs to test our hypotheses. Results show that out of eleven antecedents, seven are significantly related to the degree of communicating a family firm image. For example, the tradition orientation of the enterprising family or the number of major business partners being family firms is positively linked to the degree of revealing the family nature, while innovation intensity of the industry or the degree of internationalization of the family firm show a negative relationship with communicating a stronger family firm image. A supplementary exploration of the link between gradual revelation of the family nature and performance on brand and firm level further serves as an inspiration for future research.

Keywords: family business brand, family firm image, branding strategy, mixed methods design 


\section{Introduction}

Family firms ${ }^{1}$ are the dominant form of business across Europe, with Germany showing the highest share of family firms in Europe (Zellweger, 2017, p.25) and being particularly wellknown for its strong layer of "German Mittelstand" family firms (De Massis, Audretsch, Uhlaner, \& Kammerlander, 2018). Because of their prevalence, European family firms could even play a vivid role in corporate democratic nation-building (Anker, 2017). Thus, Europe is a particularly interesting context for family firm research. Recently, management scholars and practitioners have become increasingly interested in the phenomenon of family business branding (e.g., Beck \& Prügl, 2018; Binz, Hair, Pieper, \& Baldauf, 2013; Craig, Dibrell, \& Davis, 2008; Krappe, Goutas, \& von Schlippe, 2011; Lude \& Prügl, 2018; Zellweger, Eddleston, \& Kellermanns, 2010; Zellweger, Kellermanns, Eddleston, \& Memili, 2012), which is also reflected in recent reviews (Beck, 2016; Binz Astrachan, Botero, Astrachan, \& Prügl, 2018; Sageder, Mitter, \& Feldbauer $\square$ Durstmüller, 2018). The importance of brand management, in general, is indisputable, as a strong brand, for example, enhances consumer value creation (Anker, Sparks, Moutinho, \& Grönroos, 2015), enhances customers' brand loyalty (Chaudhuri \& Holbrook, 2001), helps distinguish from competitors (Aaker, 2004; Kastanakis \& Balabanis, 2012), positively influences new product evaluations (Besharat, 2010), and thus increases company performance through brand equity (LaPlaca, 2010). Consequently, a strong brand increases firm value and adds to the survival of the firm.

A family business brand is based on the identity of the family firm. A family firm identity is a unique combination of the corporate identity and the family identity (Zellweger et al., 2010; Zellweger et al., 2012). Consequently, the degree of communicating the family firm image (FFI) has been shown to potentially serve as a competitive advantage (e.g., Beck \& Kenning, 2015; Binz et al., 2013; Carrigan \& Buckley, 2008; Craig et al., 2008; Gallucci, Santulli, \& Calabrò, 2015). However, recent research indicates that being perceived as a family business does not elicit solely positive associations or perceptions (e.g., Botero, Binz Astrachan, \& Calabró, 2018; Hsueh, 2016).

But, while insights into the stakeholders' perception have made substantial advances (for recent examples see Arijs, Botero, Michiels, \& Molly, 2018; Beck \& Prügl, 2018; Botero, Binz

\footnotetext{
${ }^{1}$ This study defines a family firm as "a business that is governed and/or managed with the intention to shape and pursue a vision held by a dominant coalition controlled by members of the same family or a small number of families in a manner that is potentially sustainable across generations of the family and families" (Chua, Chrisman, \& Sharma, 1999, p. 25).
} 
Astrachan, \& Calabrò; 2018; Lude \& Prügl, 2018; Schellong, Kraiczy, Malär, \& Hack, 2018), still little is known about the family's decision to communicate an FFI. Family firms largely vary in their degree of displaying an FFI (Botero \& Blombäck, 2010; Micelotta \& Raynard, 2011). In fact, sometimes major stakeholders even do not know about the family nature of the firm. In a pioneering study, Binz Astrachan and Botero (2017) addressed the question why some family firm managers decide to hide the family nature of their firms while others actively communicate it creating strong family business brands. However, it remains widely unexplored what antecedents influence the degree of communicating an FFI. Hence, this study addresses the following central research question: What are the antecedents of the managerial decision regarding the degree to which an FFI is communicated?

Answering this question calls for a mixed methods design that is particularly well-suited to "provide insight into the mechanisms and boundaries of complex phenomena" (Reilly \& Jones, 2017, p.185) and that also integrates existing knowledge (Kastanakis, 2018; Van Dun, Hicks, \& Wilderom, 2017). Study 1 draws upon literature and expert interviews with executives of German family firms varying in their degree to reveal their family nature to identify potentially influential antecedents. Study 2 then assesses these antecedents' effect sizes and direction by gathering data from computer-assisted-telephone-interviews (CATIs) with 196 CEOs of German Mittelstand family firms. Lastly, we provide a first exploration of the decision's relationship with subjective and objective performance measures.

The major contributions of this article are three-fold. First, this study adds to the current understanding of the decision behind family firm branding by identifying and testing factors related to the managerial decision to what degree to communicate an FFI. This approach follows the call to recognize family firm's heterogeneity regarding their branding strategies (Binz Astrachan \& Botero, 2017; Botero \& Blombäck, 2010; Micelotta \& Raynard, 2011) and overcomes limitations of pioneering work that conceptualizes this decision as a dichotomous one (e.g., Binz Astrachan \& Botero, 2017). Thereby, the antecedents emerging from study 1 acknowledge different levels (environment, firm, and family) and thus offer a more fine-grained conceptualization of the gradual decision to reveal a family business brand. Second, these antecedents are further tested in a large-scale quantitative study adding to the current understanding of the antecedents' and their corresponding levels' relative importance when deciding on the FFI. To the best of our knowledge, this is the first study offering insights into the relative importance (i.e., effect sizes) of these antecedents for the degree of revealing the family 
nature of the firm, particularly in the context of the German Mittelstand. Third, this study also presents an initial exploration of the relationship of the decision to communicate an FFI with subjective and objective performance measures in a supplementary analysis. The results underline the necessity for future research on the consequences of family firm branding decisions.

\section{From a family firm identity to communicating a family firm image}

In this work, we define corporate identity based on the organizational viewpoint framework introduced by Brown, Dacin, Pratt, and Whetten (2006) that summarizes different definitions resulting from a substantial body of literature, in four organizational viewpoints. First, corporate or organizational identity is the sum of all central, enduring, and distinctive (CED) attributes describing how the organization and thus its members see themselves. Second, the intended corporate image comprises all CED elements that the organization wants to communicate to its different stakeholders. Third, the construed corporate image describes all CED elements the organization believes that its stakeholders have in mind thinking about the organization. Fourth, corporate reputation refers to the actual image stakeholders have in mind when thinking of the organization. Drawing on the organizational viewpoint framework, Binz Astrachan et al. (2018) differentiate three conceptualizations of the family business brand: (1) The identity view of the family business brand focuses on what family business owners and leaders believe to be true about their organization, which includes characteristics they view as differentiating factors of their business. (2) The image view of the family business brand pertains to whether and how the business owners and leaders choose to portray the family nature of their business to internal and external stakeholders. Lastly, (3) the reputation view of the family business brand captures the unique perceptions that external stakeholders consider as the differentiating factors for family firms.

This paper focuses on the image view of the family business, a less researched perspective (for notable exceptions see Table 1) in comparison to the other two central viewpoints (identity and reputation). But still, the image view of the family business brand is the result of a central and multifaceted decision to which degree to include the portrayal of the businesses' family nature to internal and external stakeholders - for example, in terms of how prominently the family or its past is featured in corporate communication (Micelotta \& Raynard, 2011). However, strongly communicating the family nature of the firm might also carry additional costs for the family and its members (e.g., giving up family privacy to some degree). 
The few pioneering studies (see Table 1) researching the FFI can be structured along four major foci: (1) Most scholars argue that the FFI grows out of the family firm identity (e.g., Binz Astrachan \& Botero, 2017; Botero et al., 2013; Memili, Eddleston, Kellermanns, Zellweger, \& Barnett, 2010; Presas, Muñoz, \& Guia, 2011; Zellweger et al., 2012). (2) Other scholars focus on the degree to which companies communicate the FFI (e.g., Blombäck \& Brunninge, 2013; Fischer \& Reuber, 2007; Micelotta \& Raynard, 2011). These investigations show that the decision about whether to communicate their FFI is not a dichotomous one. (3) Empirical studies primarily focus on the US or European context while no study explicitly deals with German Mittelstand family firms, except for Binz Astrachan \& Botero (2017). (4) Lastly, some studies examine the underlying aims and motives that family firms pursue by communicating an FFI and others examine the consequences of doing so (e.g., Binz Astrachan \& Botero, 2017; Blombäck \& Brunninge, 2016; Craig et al., 2008; Gallucci et al., 2015; Kashmiri \& Mahajan, 2010, 2014). However, to the best of our knowledge, no study attempts to empirically examine antecedents and their consequences while acknowledging different degrees of revealing the family nature of the firm.

--- Insert Table 1 about here ---

This paper acknowledges the heterogeneous nature of family firm branding by looking at the degree of communicating an FFI. In doing so, we build upon the important work of two groups of scholars. First, Memili et al. (2010) present firm manager's evaluations on a six-item scale assessing the "degree to which the organization attempts to create a family firm's image" (p. 204). Second, Micelotta and Raynard (2011) analyze websites of family firms to derive three different branding strategies based on the different elements that are communicated through this online channel: (P) family preservation, (E) family enrichment, and (S) family subordination strategy. Thereby, companies pursuing the family $(\mathrm{P})$ preservation strategy leverage the FFI the most by referring to past achievements and to the outstanding role of the family as the conservator of the tradition. On the contrary, firms following the (E) enrichment strategy trace the pathway from past to future by specifically concentrating on product and service progress. Companies complying with the (S) subordination strategy distance themselves from the past as to pave the way for future development. Thus, they do not actively communicate the FFI mimicking a nonfamily firm. 
The declining degree of family focus among these strategies demonstrates that a couple of firms spare capitalizing on their background for some reason. According to Blombäck and Brunninge (2016), family firms shape their corporate communications and reveal their family nature to evoke perceptions as authentic, high-quality, reliable, sustainable, responsible, and accountable. On the contrary, the disclosure may be restricted if too much publicity threatens the privacy of the family or excessive personification puts the brand at risk in case of personal failure (Binz Astrachan \& Botero, 2017). While pioneering studies describe reasons why to present or hide the FFI, this study follows Memili et al. (2010) and Micelotta and Raynard (2011) and acknowledges the heterogeneous nature of family firm branding. In the following, a mixed method approach is presented that allows to explore antecedents of the decision regarding this fine-grained continuum of revealing the family nature of the firm. In addition, we present initial insights on potential consequences of varying degrees of communicating a FFI.

\section{Methodological procedure}

We follow an exploratory sequential mixed methods multistudy design (Reilly \& Jones, 2017; for an overview of the studies see Figure 1). We first conduct a qualitative study (i.e., expert interviews with family firm executives) to deepen the understanding for reasons and barriers of this particular branding decision (Hausman, 2005). Subsequently, we formulate hypotheses grounded in our insights and prior literature on potential antecedents as a result of study 1 . The hypotheses are then summarized in a conceptual model and tested in a quantitative study 2 assessing each antecedent's influence (N=196 family firm CEOs).

$$
\text { --- Insert Figure } 1 \text { about here --- }
$$

\subsection{Study 1: Identifying antecedents for communicating a family firm image}

\subsubsection{Sample and data collection}

Eleven semistructured interviews with family members active as top executives of eight owner-managed family firms from the German Mittelstand have been conducted. As context matters in management and entrepreneurship research (Welter, 2011), the geographical context was kept constant to minimize biasing influences. Germany was considered as suitable due to its large variance and history of family firms increasing the individual variety of firms and their economic relevance (Bergfeld \& Weber, 2011). Table 2 summarizes sample characteristics and interview specifications. To increase theoretical value, we aimed for heterogeneous family firms 
in different aspects (sector, industry, firm size, generational stage, and founding year). Some firms are represented by more than one person belonging to different generations and filling different positions within the firm.

--- Insert Table 1 about here ---

The questions in the interviews (see Appendix A) first asked about interviewee's opinion about general brand management issues. Subsequently, the perceived relevance of the family nature of the firm to their own brand management and to other family firms was addressed. After the interviews, the firms were classified according to their branding strategy based on Micelotta and Raynard (2011): (P) family preservation, (E) family enrichment, or (S) subordination strategy (see anonymized numbering in Table 2). To increase validity of that classification, company websites and brochures were independently analyzed according to criteria of text and image components (see also Blombäck \& Brunninge, 2013; Gallucci et al., 2015; Micelotta \& Raynard, 2011). Hence, additional material depicting the behavioral dimension of family firm branding enriched the interview data.

\subsubsection{Procedure for data analysis}

Two researchers coded the data independently (Krippendorff, 2004), achieving a good intercoder reliability of $82 \%$ (Holsti, 1969; Neuendorf, 2016). Percent agreement is regarded as most appropriate in management and marketing research (Dorussen, Lenz, \& Blavoukos, 2005). Disagreements were discussed and could be resolved (Krippendorff, 2004). Then, key phrases and patterns were iteratively identified (Spiggle, 1994) as potential antecedents for the focal (gradual) decision. A structuring content analysis adapted from Kotlar and De Massis (2013) allowed to identify first-order factors (step 1).

Thereby, explicitly mentioned reasons were gathered that directly explain branding decisions (step 1a). Then, implicit identity-related factors influencing the branding strategy choice were identified (step 1b). Although these statements lack an explicit link to branding strategies, as identity is latent, i.e., not directly observable, they were still considered influential as they differed widely among companies following different branding strategies. Hence, these implicit factors may not be recognized by the interviewees themselves as influential for their branding strategy decisions (Blombäck \& Ramírez-Pasillas, 2012). For example, a family firm image may solely evolve not only from a deliberate, rational, and conscious decision, but also 
from an intuitive or emergent process. When comparing the extracted factors among family firms with different branding strategies (step 2), some lacked variance, i.e., all firms, independent of their branding strategy, showed the same characteristics (e.g., focus on quality and long-term orientation). Although this is not surprising (see also Zellweger et al., 2012), these factors were dropped as they do not contribute to explaining family firms' heterogeneity regarding their branding decision. Next, second-order themes were defined by iteratively consolidating the first-

order factors (step 3). Finally, the second-order themes were aggregated (step 4) and resulted into three different aggregated dimensions: (1) environment, (2) business, and (3) family.

\subsubsection{Results of study 1 and hypotheses development}

Eleven antecedents were identified that potentially affect to what degree a family firm image is communicated (see Figure 2). To develop hypotheses, these factors were substantiated by prior findings whenever possible.

\section{--- Insert Figure 2 about here---}

\section{Hypotheses related to the dimension "Environment"}

Two antecedents of this aggregate dimension emerged from the data. First, innovation pressure in an industry to market new products or services has been shown to influence the branding strategy (Craig et al., 2008; Micelotta \& Raynard, 2011). Our data support this notion indicating that it might affect the managerial decision to communicate the family firm brand as well. For example, the interviewee of S2 states: "A family firm image makes sense in case of traditional products (...), computers are not that traditional though" and "family firms and technological innovation do not work well together." On the contrary, P2 is very proud to still sell products that have existed for more than 60 years. Others such as E2 and E3 generate revenue through individualized and customer-oriented products instead of advanced technology and innovation. In consequence:

Hypothesis 1a: The higher the innovation intensity of an industry, the less a family firm communicates a family firm image.

Second, it seems to be influential whether the competitors present themselves as family firms. In fact, the presence of many family firms within the same market leads to the situation that S2 cannot distinguish itself from the competition by means of the family firm image; it rather uses other elements such as its innovativeness. This relation between the branding strategies of 
the firm and its competitors is reflected in the differentiation function of brand management in general (Aaker, 2004). Likewise, the interviewee of P1 states: "Well, [following a preservation strategy] we have a trust advantage compared to other competitors from the eyes of our customers" only due to its family firm image. Thus, we formulate:

Hypothesis 1b: The more family firms among its competitors, the less a family firm communicates a family firm image.

\section{Hypotheses related to the dimension "Business"}

Four antecedents emerged from study 1 on that aggregated dimension. First, the market sector appears to affect the branding strategy (Botero et al., 2013; Kashmiri \& Mahajan, 2010; Veloutsou \& Taylor, 2012). Interviewees from S1 claim multiple times that the effort to exploit the family firm image would not be worth it, as the firm addresses the B2B sector where a family firm image is hardly appreciated in their opinion. In contrast, the interviewee of P2 emphasizes that the end "consumer is more than ever crazy about family and family firms." Thus, we hypothesize:

Hypothesis 2a: A family firm operating in the B2B sector is less likely to communicate a family firm image (compared to family firms in the B2C sector).

Furthermore, in line with Micelotta and Raynard (2011), our data indicate the impact of firm size. For instance, the interviewee of E3 states: "Family firms are perceived positively in case that they are rather small." Similarly, the family executives of S2, a comparably large firm, told us that their marketing department proposed an anniversary celebration to emphasize the family firm image. However, they rejected that idea because of concerns about losing the perception of professionalism. Apart from these perception-related aspects, the self-conception as family firm is relatively strong among small companies. For instance, the interviewee of P1 claims to barely classify itself as Mittelstand firm, but due to its size rather as family firm. Thus:

Hypothesis 2b: The larger a family firm is, the less it communicates a family firm image.

Third, another antecedent emerging from our data and supported by prior research is the degree of a firm's international activities (Micelotta \& Raynard, 2011). Country-specific cultures (Botero et al., 2013; Sundaramurthy \& Kreiner, 2008) seem to be decisive for the branding choice in that context. For instance, the interviewee of E2 doubts whether the family firm image makes any difference or may even be perceived negatively in countries such as Russia or China where the corresponding firm is actively engaged: "Small companies that deliver to delicacy 
shops on a regional basis come naturally to put 'family firm' on the packaging (...), in the global market we operate in, it [the family firm image] would get lost though.” In line, P1 that mainly operates regionally builds upon the family origin of the firm. Hence:

Hypothesis 2c: The more a family firm operates internationally, the less it communicates a family firm image.

Forth, the number of family firms among major business partners seems to play a crucial role. E3 and S2 have experienced to be notably valued by business partners that regard themselves as family firms. According to the interviewee of E2, especially suppliers, which are themselves rich in tradition, favor family firms as business partners. This is in line with findings on supplier selection, where mutual understanding and trust of the parties decide on the selection of business partners along the supply chain (Punniyamoorthy, Mathiyalagan, \& Parthiban, 2011). Because of this "perceived similarity" effect, we argue:

Hypothesis 2d: The more family firms are among its major business partners, the more a family firm communicates a family firm image.

\section{Hypotheses related to the dimension "Family"}

Five antecedents emerged within this aggregate dimension. In line with prior literature, our data indicate probability of family succession as an antecedent of branding decisions (Hauswald \& Hack, 2013). On this matter, E4's executive states: "The risk of family firms is the probable lack of a family successor so that the firm must be sold leading to a rupture [regarding the brand]." Furthermore, considering the medium- to long-term effects of branding decisions in general and the integration of the family nature of the firm in branding activities in particular, family firms might be hesitant to communicate a stronger family firm image, if the owning family assumed that this branding strategy was not sustainably supportable by family-internal succession (e.g., if the firm has to be sold to a family-external entity). In accordance, the brand of P2 embodies continuity transmitted by the family and it is further ensured, thanks to the third generation willing to overtake. Thus:

Hypothesis 3a: The lower the probability of family-internal succession, the less a family firm communicates a family firm image.

Moreover, the influence of family members on marketing issues was identified. For instance, one interviewee of S1, who has recently joined the firm, was advised by the firm's marketers to appear frequently together with her fiancée at events and dinners to emphasize the 
family firm image in the public. They followed this advice leaving the marketing strategy primarily to the marketers' evaluation. On the contrary, the family involvement into marketing activities was shown to have a positive effect on communicating the family firm image (Deephouse \& Jaskiewicz, 2013; Gallucci et al., 2015) as manifested by the family executive of $\mathrm{P} 1$. He is the only one in charge of the branding strategy, which leverages the family firm image to a great extent. Thus, we formulate nondirectional:

Hypothesis 3b: The influence of family members on marketing affects the degree of communicating a family firm image.

Third, tradition orientation of the respective family members was identified as potential antecedent. In this vein, P1 upholds the corporate tradition: "It almost looks like a museum up here. (...) I definitely like that and feel comfortable here." Similarly, the interviewee of E3 exhibits the pride about the corporate tradition by stating that the firm still sticks to the traditional techniques within the manufacturing process that have survived for more than a hundred years. Likewise, in E4, the firm founders are still considered as icons. The families of such firms whose conduct is still guided by their tradition show pride in their ancestors and established action patterns (Binz Astrachan \& Botero, 2017; Micelotta \& Raynard, 2011; Zellweger et al., 2012). In contrast, E1 and E2 build upon tradition by linking it to technology and innovation. S1 and S2 are more distanced from tradition and corporate history. For instance, S1's executive states: "We have retained the modernism throughout the history or have often got back to it before losing ground. Thus, we fall back on a long history, but we are not outdated which happens often to family firms resembling rather a museum." Similarly, S2 considers their history to be highly fascinating but inadequate to be communicated in the professional environment of a competitive firm. Thus:

Hypothesis 3c: The more the owning family focuses on tradition, the more a family firm communicates a family firm image.

Innovation orientation seems to be essential to the branding strategy decision as well. For instance, P2 restricts innovation to new package designs and communication strategies. Other companies, such as $\mathrm{S} 1, \mathrm{~S} 2$, and E1, prioritize innovation to a greater degree. E1 envisions the firm as a pioneer, seeing innovation as necessary, sometimes even at the expense of or by gradually changing traditional values. For E1, the incompatibility of innovativeness and familiarity that seems to exist in the eye of consumers does not hold. As opposed to this, interviewees of $\mathrm{S} 1$ emphasize that the firm competes daily to distance itself of the old-fashioned 
image of family firms to pave the way for innovation. In addition, S2 does not want to be associated with pseudo-innovation as the firm tries hard to innovate substantially thus refraining from a family firm image. Therefore:

Hypothesis 3d: The more the owning family focuses on innovation, the less a family firm communicates a family firm image.

Lastly, interviewees themselves vary in their extraversion. For instance, the interviewee of $\mathrm{P} 2$ enjoyed being interviewed by a television channel about the corporate history and later put on TV. Others, such as the interviewee of E4, view the former executive of the respective firm as the "Grande Dame" and highly value the impression that family members could have on the public. Such extravert family members do not seem to feel uncomfortable about the risk of negative effects on the reputation of the family or the firm (Bravo, Cambra, Centeno, \& Melero, 2017). In contrast, interviewees from $S 1$ are rather reluctant to represent the firm externally. In fact, they claim: "We are proud of our capabilities, but we feel ashamed of such pride and do not extravert it." This attitude is similar to the interviewee of E2, who does not want to be the center of attention, and the one of E1 stating: "We don't boost our family's profile." Other firms such as $\mathrm{S} 2$ claim to be even more reserved and modest, avoiding public attention as much as possible indicating the following:

Hypothesis 3e: The more extraverted a family CEO is, the more a family firm communicates a family firm image.

\section{Additional factors}

Despite the breadth and depth of the insights from the interviews, some factors need to be considered in face of pioneering scholarly suggestions. These are the generational stage as well as the founding year (Botero et al., 2013; Sundaramurthy \& Kreiner, 2008; Zellweger et al., 2012), the number of family members active in the management board and as employees (Sundaramurthy \& Kreiner, 2008), and the percentage of family ownership (Deephouse \& Jaskiewicz, 2013). In addition, we decided to assess the influence of an external marketing consultancy as hypothesis $\mathrm{H} 3 \mathrm{~b}$ remains nondirectional. Figure 3 and Table 3 summarize all hypotheses including additional quotes from our interviewees.

--- Insert Table 3 about here ---

--- Insert Figure 3 about here --- 


\subsection{Study 2: Testing antecedents for communicating a family firm image}

The quantitative study 2 aims at testing the hypotheses resulting from study 1 . In addition, as suggested by several scholars (e.g., Binz Astrachan \& Botero, 2017; Binz et al., 2013; Craig et al., 2008; Okoroafo \& Koh, 2009; Orth \& Green, 2009), the relationship of the degree of communicating a family firm image with brand and firm performance is explored in a supplementary analysis.

\subsubsection{Sample and data collection}

Data from family firm CEOs belonging to the German Mittelstand were collected with CATIs. This approach helps increase the response rate compared to mass mailings and improves data quality as undesired response patterns (e.g., other respondents than the family CEO) are avoided. Four sample selection criteria were required for participation. Family firms needed (1) to belong to the German Mittelstand, (2) to be owner-managed with at least a $50 \%$ share of family ownership, (3) to have 10 to 3000 employees, and (4) to be older than ten years to differentiate them from start-ups. To increase the heterogeneity on the focal variables, we defined rates on firm size (i.e., number of employees) and the market sector for our stratified sample to achieve equal group sizes. Other approaches would have led to an overrepresentation of small family firms (with 10 to 50 employees) primarily being located within the $\mathrm{B} 2 \mathrm{C}$ sector. Overall, approximately 7,000 companies meeting the selection criteria were identified via an extensive database (DAFNE), and contact details of the family CEOs were added manually from online archives. These data were passed on to an independent research agency that randomly called the family firms. From approximately 2,000 contacted companies, 196 completed the questionnaire leading to a response rate of approximately $10 \%$. The sample characteristics are summarized in Table 4.

\section{--- Insert Table 4 about here ---}

The questionnaire consisted of five parts: (1) firm characteristics, (2) questions on the subjective brand performance in comparison to the strongest competitor in the marketplace (Matear, Osborne, Garrett, \& Gray, 2002), (3) the degree to which a company promotes the family firm image (Memili et al., 2010), (4) the antecedents and relevant control variables, and (5) demographic data of the interviewees (for all operationalization of the focal constructs, see 
Appendix B). Additionally, we gathered sales data from the firms ${ }^{2}$ to relate subjective and objective performance data to the degree a family firm promotes its family nature in a supplementary analysis (see Figure 3).

\subsubsection{Data analysis and results}

Partial least square structural equation modeling (PLS-SEM) was used to test the hypotheses (Hair, Ringle, \& Sarstedt, 2011). We acknowledge the criticism regarding the effectiveness of PLS-SEM for testing hypotheses as it is suspected to potentially draw an overly positive picture due to inconsistent and biased parameter estimates (Rönkkö \& Evermann, 2013). Nonetheless, we consider the variance-based PLS-SEM as most suitable approach for our complex model as (1) it allows us to include many variables without the loss in statistical prediction efficacy and (2) it is a composite factor model (Hair, Hult, Ringle, Sarstedt, \& Thiele, 2017; Henseler et al., 2014; Henseler, Ringle, \& Sarstedt, 2015; Sarstedt, Hair, Ringle, Thiele, \& Gudergan, 2016). In addition to the identified antecedents, we controlled for the current generation leading the business, the data assessment type ${ }^{3}$, family members in the management board and as other employees, the founding year, the influence of an external marketing consultancy, and the percentage of family ownership.

Before testing the hypotheses, we analyzed the model for its validity, reliability, and fit indices. Both the Fornell-Larcker criteria (Fornell \& Larcker, 1981) and the HeterotraitMonotrait ratio (Henseler et al., 2015) indicate a good discriminant validity among the used concepts. Variance inflation factors show a maximum value of 1.8 , indicating no multicollinearity in the context of PLS-SEM (Kock \& Lynn, 2012). Model fit indices can be characterized as acceptable with SRMR of 0.075 (Hu \& Bentler, 1999), NFI of 0.603, and Chi² of 1,364.899 (Hooper, Coughlan, \& Mullen, 2008; Tomarken \& Waller, 2003). All constructs can be considered as reliable, with composite reliabilities ${ }^{4}$ higher than 0.8 (Hair et al., 2014). The

\footnotetext{
${ }^{2}$ Objective performance data (average of sales in the last three years) were derived from DAFNE database.

${ }^{3}$ Some respondents contacted through telephone asked to answer the questions paper-based. There was no significant influence of that variable. In addition, no significant differences were observed when comparing means of the independent and dependent variables from the group answering through telephone vs. paper-based.

${ }^{4}$ Applying PLS-SEM makes composite reliability the more accurate reliability indicator compared to Cronbach's alpha (Hair et al., 2011; Hair, Sarstedt, Hopkins, \& Kuppelwieser, 2014).
} 
average variance extracted shows values higher than 0.5 , indicating convergent validity (for details see Appendix B). ${ }^{5}$

As depicted in Table 5 and Figure 4, seven antecedents from the three aggregated dimensions (environment, business, and family) have a significant impact on FFI, i.e., the degree to which a company promotes a family firm image $\left(\mathrm{R}^{2}=0.351\right)$.

Environment. Innovation intensity of the industry is significantly related to FFI $\left(\beta=-.105^{*}\right.$; $t=1.611$ ), lending support to $\mathrm{H} 1 \mathrm{a}$, while $\mathrm{H} 1 \mathrm{~b}$ (family firms as competitors) has to be rejected.

Business. B2B sector $(\beta=-.082 * ; t=1.283)$, firm size $(\beta=-.0 .073 * ; t=1.622)$, the degree of internationalization $(\beta=-.127 * * * ;=2.392)$, as well as the number of family firms as major business partners $(\beta=.140 * ; t=2.132)$ are significantly related to the promotion of the family nature of the firm. Accordingly, we find support for $\mathrm{H} 2 \mathrm{a}, \mathrm{H} 2 \mathrm{~b}, \mathrm{H} 2 \mathrm{c}$, and $\mathrm{H} 2 \mathrm{~d}$.

Family. The two family-related antecedents with a significant impact are the tradition orientation being positively related to the FFI $(\beta=.247 * * * ; t=3.901)$ lending support to $\mathrm{H} 3 \mathrm{c}$, and the degree of extraversion of the family firm CEOs significantly and positively affecting FFI $\left(\beta=.158^{*}\right.$; $t=2.285$ ), indicating the confirmation of $\mathrm{H} 3 \mathrm{e}$. On the contrary, H3a (probability of family succession), H3b (family influence on marketing), and H3d (innovation orientation of the owning family) have to be rejected.

\section{--- Insert Table 5 about here --- \\ --- Insert Figure 4 about here ---}

Controls. We controlled for several variables. Within our data set, significant effects on FFI were observed from the number of family members within the management board $(\beta=.148 * *$; $t=2.049)$ and from the founding year $(\beta=-.280 * * ; t=4.088)$.

Supplementary analysis on performance. FFI shows a significant positive relationship with performance in terms of sales $\left(\beta=.161 * * ; t=3.066 ; R^{2}=0.040\right)$ as well as on the subjectively assessed brand performance $\left(\beta=.202 * * * ; t=2.372 ; R^{2}=0.026\right)$.

\section{Discussion}

The main contributions of this study are three-fold. First, it adds to pioneering insights from Binz Astrachan and Botero (2017) regarding the understanding of the decision behind

\footnotetext{
${ }^{5}$ However, one construct (family firm image - the operationalization for the degree of communication of the family firm image - FFI) showed a value of 0.472. After checking the outer loadings and considering the composite reliability of the FFI construct, we refused from deleting an item as all loadings were higher than 0.585 .
} 
family firm branding by integrating qualitative and quantitative elements from a mixed methods design. Accordingly, a model of potential and actual antecedents to the managerial decision to which degree to communicate a family firm image was explored and tested in the European context (German Mittelstand family firms). Two aspects of this study allow for a more finegrained understanding of these antecedents: (1) the consideration of personality- and attituderelated factors observed in our interviews with family firm executives as well as in the literature, and (2) the recognition of the continuous nature of the outcome variable (i.e., FFI as the degree of revealing the family nature of the firm) instead of a dichotomous conceptualization. The latter helps to account for the existent heterogeneity of family firm branding strategies. Synthesizing these rich data with important prior research led to the identification of three dimensions aggregating different antecedents mentioned or observed to influence the degree of building a family firm image: (1) environment, (2) business, and (3) family. Hence, considering the heterogeneous nature of the family firm image allowed to identify antecedents beyond the identity- and outcome-related motives and constraints previously explored by Binz Astrachan and Botero (2017). This might help future studies to mitigate the potential of omitted variable bias when researching family firm branding strategies.

Second, study 2 contributes to the understanding of the antecedents' and their corresponding levels' relative importance when deciding on the family firm image. Seven antecedents from the aggregate dimensions identified in study 1 determine the degree to which the family nature of the firm is revealed. In detail, these relate to the environment (innovation intensity of the industry), the business (B2B sector, firm size, degree of internationalization, and family firms among major business partners), and the family (tradition orientation and extraversion of the family CEO). All of them are either significantly positively or negatively linked to the degree of communicating a family firm image in line with our hypotheses. Thereby, the effect sizes of these factors vary indicating differences in the strength of their respective influence. While tradition orientation (i.e., family level) shows the strongest effect on this decision, market sector (B2B) and firm size (i.e., business level) seem to be comparably less relevant. This might be due to the possibility of establishing product brands instead of corporate brands covering the real firm size from the eyes of some stakeholder groups such as customers. For example, the spirits company William Grant \& Sons does strongly communicate their family nature for the overall firm while this is different for their products: Family firm branding is 
extensively used for the whiskey brand "Glennfiddich," but not for the gin brand "Hendricks" (see company website williamgrant.com).

These findings confirm, enrich, but also contradict prior findings. Although the role of the innovation intensity of the industry (Micelotta \& Raynard, 2011) and the B2B sector (Craig et al., 2008; Kashmiri \& Mahajan, 2010) confirm existing findings (but in a different context), family ownership (Deephouse \& Jaskiewicz, 2013; Gallucci et al., 2015) did not show a significant relative effect within the thresholds of our sample of German Mittelstand family firms. Moreover, our findings regarding firm size, the degree of internationalization, family firms among major business partners, or tradition orientation and the extraversion of the family CEO enrich prior knowledge on family business branding. Four antecedents discovered in study 1, however, did not show a significant influence. First, this applies to the family influence on marketing. To better understand the reasons, the specific type of the involvement of the enterprising family (e.g., involvement of next generation family members or not) might be interesting to examine. Second, more surprising is the nonsignificance of the likelihood of family-internal succession. One reason could be that if the family-internal succession is uncertain and selling the firm is an option, then both hiding and revealing a family firm image might increase the brand value and, hence, the company value - at least in the short-run and depending on the bidder. Third, while study 1 suggests a negative effect of the enterprising family's innovation orientation on communicating a family firm image, study 2 interestingly did not reveal any significant effect. This might be due to a dominant effect of the innovation intensity of the industry that could relatively diminish the influence of a family firm's innovation orientation on the degree of revealing their family firm image. Fourth, while family firms as partners positively influence the communication of a family firm image, the number of family firms as competitors does not have a significant effect in the context of our sample. This might be due to the particularistic nature of strategic decisions in family firms allowing relatively autonomous decision-making (Carney, 2005). Taken together, these results provide a rich ground for conceptualizing future studies.

Third, by providing supplementary results merging the survey data with archival data, this study adds initial insights on the relationship between the degree of revealing a family firm image and performance. While our results add to the limited number of existing studies pointing toward a positive relationship of more openly communicating the family nature of the firm with objective (Gallucci et al., 2015; Kashmiri \& Mahajan, 2010) and, considering the effect sizes, especially with subjective performance (Craig et al., 2008), these results have to be interpreted 
with caution because of limited explanatory power $\left(\mathrm{R}^{2}=.026 / .040\right)$. They are rather meant to inspire future research to further advance our understanding of performance implications in more detail. Although factors, beyond branding, might further explain performance variances, the small but significant effect sizes indicate that these relationships could be influenced by boundary conditions that are still up for discovery. For example, a strong family firm image might lead to an increased brand authenticity or purchase intention (Beck \& Prügl, 2018; Lude \& Prügl, 2018) but not under all circumstances to an increased willingness-to-pay or real-world purchase. Thus, it becomes clear that communicating a family firm image cannot be regarded as a one-size-fits-itall branding solution. Rather, these findings indicate that different boundary conditions demand further exploration.

\section{$5 \quad$ Managerial implications}

Our findings support the observation that family firms do not automatically favor a family firm branding strategy but behave rather heterogeneously as indicated by a high variance in the FFI construct (Mean=5.2; $\mathrm{SD}=1.4 ; \min =1.0 ; \max =7.0)$. Both the executives' personality traits and core values of the enterprising family seem to influence this managerial decision. Extraversion of decision-makers or tradition orientation of the family alters considerations about the extent of communicating a family firm image. Furthermore, certain circumstances such as a B2B context, or a big firm size, inhibit a more open communication of the family nature of their firm. Likewise, family firms being active in a several different countries seem to be hesitant to prominently integrate their family firm identity into branding. This might be due to the mixed signals a family firm image provokes in different cultural and country-specific contexts around the globe (Botero, Binz Astrachan, \& Calabro, 2018). On the contrary, strongly communicating a family firm image seems to be especially likely if major business partners are family firms themselves. This might evoke similarity perceptions (birds of a feather flock together) and could be particularly helpful to face the challenges of internationalization by forming joint ventures, or strategic alliances. Here, the family nature could serve as a common ground enabling the development of trustful relations. Another interesting implication arises from the industrial context: family firm executives reduce the communication of a family firm image in industries with high innovation intensities. For example, family firms active in the IT and software sectors rather refrain from very openly communicating a family firm image. Knowing about these antecedents helps family firm managers and consultants alike to reduce the complexity of the important decision on how strongly to emphasize the family nature of the firm. 


\section{Limitations and further research}

Our studies have limitations offering opportunities for further research. First, despite many factors identified in our first exploratory study, we do not claim to present a holistic explanation for family firms' heterogeneity of communicating a family firm image. Although our study focuses on the microfoundations (i.e., the family members' perspective), institutional circumstances (e.g., firm's founding year, degree of family ownership, and external investors) might be important for the branding decision (Deephouse \& Jaskiewicz, 2013; Sundaramurthy \& Kreiner, 2008). Despite addressing some of these factors as control variables in study 2 (e.g., founding year, influence of branding agency, and generational stage), there might be more relevant antecedents. Moreover, while the focus on one single context could be considered as a particular strength of our approach increasing the internal validity of our findings (e.g., Hauck \& Prügl, 2015), the generalizability is limited. Further studies, thus, should test and extend our framework to other European and non-European contexts outside Germany's Mittelstand firms (e.g., by considering factors such as long-term orientation that were dropped because of a lack of variance in the German context).

Second, although study 2 has assessed the relationship of family firms' decision to communicate a family firm image with brand (subjective measure) and firm performance (objective measure), we emphasize the relevance of investigating further performance effects (e.g., profits or customer retention) of that branding strategy. Especially, the identification of moderating boundary conditions (e.g., Gallucci et al., 2015) would advance the understanding of the consequences of communicating a family firm image. Future studies also need to address causality issues, for example, by applying longitudinal and experimental research designs to empirically demonstrate the consequences of a stronger communication of a family firm image on firm performance.

In line with Neubaum (2018), we believe that branding-related issues in the context of family business research are still underrepresented. We have still very limited knowledge about how, when, and why family businesses choose to emphasize their family nature in branding activities (Binz Astrachan \& Botero, 2018; Binz Astrachan et al., 2018). Bearing in mind the importance of brand management for long-term firm performance and survival, "it would seem that understanding the value of a family brand would be just as important to family business scholars (and family businesses owners) as how to successfully manage the succession process or foster transgenerational entrepreneurship" (Neubaum, 2018, p. 265). Accordingly, we hope to 
encourage scholars from management, marketing, as well as family business to embark on that endeavor. 


\section{References}

Aaker, D. A. (2004). Leveraging the corporate brand. California Management Review, 46(3), 618.

Allayannis, G., Ihrig, J., \& Weston, J. P. (2001). Exchange-rate hedging: Financial versus operational strategies. American Economic Review, 91(2), 391-395.

Anderson, R. C., \& Reeb, D. M. (2003). Founding $\square$ family ownership and firm performance: evidence from the S\&P 500. Journal of Finance, 58(3), 1301-1327.

Anker, T. B. (2017). Corporate democratic nation-building: Reflections on the constructive role of businesses in fostering global democracy. In Management Research (pp. 159-174): Routledge.

Anker, T. B., Sparks, L., Moutinho, L., \& Grönroos, C. (2015). Consumer dominant value creation: A theoretical response to the recent call for a consumer dominant logic for marketing. European Journal of Marketing, 49(3/4), 532-560.

Arijs, D., Botero, I. C., Michiels, A., \& Molly, V. (2018). Family business employer brand: Understanding applicants' perceptions and their job pursuit intentions with samples from the US and Belgium. Journal of Family Business Strategy, 9(3), 180-191.

Beck, S. (2016). Brand management research in family firms-a structured review and suggestions for further research. Journal of Family Business Management, 6(3), 225-250.

Beck, S., \& Kenning, P. (2015). The influence of retailers' family firm image on new product acceptance: an empirical investigation in the German FMCG market. International Journal of Retail \& Distribution Management, 43(12), 1126-1143.

Beck, S., \& Prügl, R. (2018). Family firm reputation and humanization: Consumers and the trust advantage of family firms under different conditions of brand familiarity. Family Business Review, 31(4), 460-482.

Bergfeld, M.-M. H., \& Weber, F.-M. (2011). Dynasties of innovation: Highly performing German family firms and the owners' role for innovation. International Journal of Entrepreneurship and Innovation Management, 13(1), 80-94.

Besharat, A. (2010). How co-branding versus brand extensions drive consumers' evaluations of new products: A brand equity approach. Industrial Marketing Management, 39(8), 12401249. 
Binz Astrachan, C., Botero, I., Astrachan, J. H., \& Prügl, R. (2018). Branding the family firm: A review, integrative framework proposal, and research agenda. Journal of Family Business Strategy.

Binz Astrachan, C., \& Botero, I. C. (2017). "We are a family firm" An exploration of the motives for communicating the family business brand. Journal of Family Business Management.

Binz, C., Hair, J. F., Pieper, T. M., \& Baldauf, A. (2013). Exploring the effect of distinct family firm reputation on consumers' preferences. Journal of Family Business Strategy, 4(1), 311.

Blombäck, A., \& Brunninge, O. (2013). The dual opening to brand heritage in family businesses. Corporate Communications: An International Journal, 18(3), 327-346.

Blombäck, A., \& Brunninge, O. (2016). Identifying the Role of Heritage Communication: A Stakeholder-Function Framework. International Studies of Management \& Organization, 46(4), 256-268.

Blombäck, A., \& Ramírez-Pasillas, M. (2012). Exploring the logics of corporate brand identity formation. Corporate Communications: An International Journal, 17(1), 7-28.

Botero, I. C., \& Blombäck, A. (2010). Leveraging the family brand: using brand management to highlight the advantages of family firms. Paper presented at the 10th Annual IFERA World Family Business Research Conference.

Botero, I. C., Thomas, J., Graves, C., \& Fediuk, T. A. (2013). Understanding multiple family firm identities: An exploration of the communicated identity in official websites. Journal of Family Business Strategy, 4(1), 12-21.

Bravo, R., Cambra, J., Centeno, E., \& Melero, I. (2017). The Importance of Brand Values in Family Business. Journal of Evolutionary Studies in Business, 2(2), 16-43.

Brown, T. J., Dacin, P. A., Pratt, M. G., \& Whetten, D. A. (2006). Identity, intended image, construed image, and reputation: An interdisciplinary framework and suggested terminology. Journal of the Academy of Marketing Science, 34(2), 99-106.

Carney, M. (2005). Corporate governance and competitive advantage in family $\square$ controlled firms. Entrepreneurship Theory and Practice, 29(3), 249-265.

Carrigan, M., \& Buckley, J. (2008). 'What's so special about family business?'An exploratory study of UK and Irish consumer experiences of family businesses. International Journal of Consumer Studies, 32(6), 656-666. 
Chaudhuri, A., \& Holbrook, M. B. (2001). The chain of effects from brand trust and brand affect to brand performance: the role of brand loyalty. Journal of Marketing, 65(2), 81-93.

Chrisman, J. J., Chua, J. H., \& Litz, R. A. (2004). Comparing the Agency Costs of Family and Non $\square$ Family Firms: Conceptual Issues and Exploratory Evidence. Entrepreneurship Theory and Practice, 28(4), 335-354.

Chua, J. H., Chrisman, J. J., \& Sharma, P. (1999). Defining the family business by behavior. Entrepreneurship: Theory and Practice, 23(4), 19-19.

Chua, J. H., Chrisman, J. J., \& Sharma, P. (2003). Succession and nonsuccession concerns of family firms and agency relationship with nonfamily managers. Family Business Review, 16(2), 89-107.

Claver, E., Rienda, L., \& Quer, D. (2009). Family firms' international commitment: The influence of family-related factors. Family Business Review, 22(2), 125-135.

Craig, J. B., Dibrell, C., \& Davis, P. S. (2008). Leveraging Family $\square$ Based Brand Identity to Enhance Firm Competitiveness and Performance in Family Businesses. Journal of Small Business Management, 46(3), 351-371.

De Massis, A., Audretsch, D., Uhlaner, L., \& Kammerlander, N. (2018). Innovation with Limited Resources: Management Lessons from the German Mittelstand. Journal of Product Innovation Management, 35(1), 125-146.

de Vries, R. E. (2013). The 24-item brief HEXACO inventory (BHI). Journal of Research in Personality, 47(6), 871-880.

Deephouse, D. L., \& Jaskiewicz, P. (2013). Do Family Firms Have Better Reputations Than Non $\square$ Family Firms? An Integration of Socioemotional Wealth and Social Identity Theories. Journal of Management Studies, 50(3), 337-360.

Dorussen, H., Lenz, H., \& Blavoukos, S. (2005). Assessing the reliability and validity of expert interviews. European Union Politics, 6(3), 315-337.

Deshpandé, R., \& Farley, J. U. (1998). Measuring market orientation: generalization and synthesis. Journal of Market-Focused Management, 2(3), 213-232.

Fischer, E., \& Reuber, R. (2007). The good, the bad, and the unfamiliar: The challenges of reputation formation facing new firms. Entrepreneurship Theory and Practice, 31(1), 5375.

Fornell, C., \& Larcker, D. F. (1981). Evaluating structural equation models with unobservable variables and measurement error. Journal of Marketing Research, 18(1), 39-50. 
Gallucci, C., Santulli, R., \& Calabrò, A. (2015). Does family involvement foster or hinder firm performance? The missing role of family-based branding strategies. Journal of Family Business Strategy, 6(3), 155-165.

Grewal, R., Mehta, R., \& Kardes, F. R. (2004). The timing of repeat purchases of consumer durable goods: The role of functional bases of consumer attitudes. Journal of Marketing Research, 41(1), 101-115.

Hair, J. F., Hult, G. T. M., Ringle, C. M., Sarstedt, M., \& Thiele, K. O. (2017). Mirror, mirror on the wall: A comparative evaluation of composite-based structural equation modeling methods. Journal of the Academy of Marketing Science, 45(5), 616-632.

Hair, J. F., Ringle, C. M., \& Sarstedt, M. (2011). PLS-SEM: Indeed a silver bullet. Journal of Marketing Theory and Practice, 19(2), 139-152.

Hair, J. F., Sarstedt, M., Hopkins, L., \& Kuppelwieser, G. V. (2014). Partial least squares structural equation modeling (PLS-SEM) An emerging tool in business research. European Business Review, 26(2), 106-121.

Hauck, J., \& Prügl, R. (2015). Innovation activities during intra-family leadership succession in family firms: An empirical study from a socioemotional wealth perspective. Journal of Family Business Strategy, 6(2), 104-118.

Hausman, A. (2005). Innovativeness among small businesses: Theory and propositions for future research. Industrial Marketing Management, 34(8), 773-782.

Hauswald, H., \& Hack, A. (2013). Impact of family control/influence on stakeholders' perceptions of benevolence. Family Business Review, 26(4), 356-373.

Henseler, J., Dijkstra, T. K., Sarstedt, M., Ringle, C. M., Diamantopoulos, A., Straub, D. W., . . . Calantone, R. J. (2014). Common beliefs and reality about PLS: Comments on Rönkkö and Evermann (2013). Organizational Research Methods, 17(2), 182-209.

Henseler, J., Ringle, C. M., \& Sarstedt, M. (2015). A new criterion for assessing discriminant validity in variance-based structural equation modeling. Journal of the Academy of Marketing Science, 43(1), 115-135.

Holsti, O. R. (1969). Content analysis for the social sciences and humanities. Don Mills: Addison-Wesley Publishing Company.

Hooper, D., Coughlan, J., \& Mullen, M. (2008). Structural equation modelling: Guidelines for determining model fit. Electronic Journal of Business Research Methods, 6(1), 53-60. 
Hsueh, J. W. J. (2016). Governance structure and the credibility gap: Experimental evidence on family businesses' sustainability reporting. Journal of Business Ethics, 1-22.

Hu, L., \& Bentler, P. M. (1999). Cutoff criteria for fit indexes in covariance structure analysis: Conventional criteria versus new alternatives. Structural Equation Modeling: A Multidisciplinary Journal, 6(1), 1-55.

Kashmiri, S., \& Mahajan, V. (2010). What's in a name?: An analysis of the strategic behavior of family firms. International Journal of Research in Marketing, 27(3), 271-280.

Kashmiri, S., \& Mahajan, V. (2014). A Rose by Any Other Name: Are Family Firms Named After Their Founding Families Rewarded More for Their New Product Introductions? Journal of business ethics, 124(1), 81-99.

Kastanakis, M. N. (2018). Letter from the incoming Editor-in-Chief. European Management Journal, 36(2), 151-152.

Kastanakis, M. N., \& Balabanis, G. (2012). Between the mass and the class: Antecedents of the "bandwagon" luxury consumption behavior. Journal of Business Research, 65(10), 13991407.

Kock, N., \& Lynn, G. (2012). Lateral collinearity and misleading results in variance-based SEM: An illustration and recommendations. Journal of the Association for Information Systems, 13(7), 546-580.

Kotlar, J., \& De Massis, A. (2013). Goal setting in family firms: Goal diversity, social interactions, and collective commitment to family $\square$ centered goals. Entrepreneurship Theory and Practice, 37(6), 1263-1288.

Krappe, A., Goutas, L., \& von Schlippe, A. (2011). The "family business brand": an enquiry into the construction of the image of family businesses. Journal of Family Business Management, 1(1), 37-46.

Krippendorff, K. (2004). Reliability in content analysis. Human Communication Research, 30(3), 411-433.

Kuckertz, A., \& Wagner, M. (2010). The influence of sustainability orientation on entrepreneurial intentions-Investigating the role of business experience. Journal of Business Venturing, 25(5), 524-539.

LaPlaca, P. J. (2010). Special issue on building, implementing, and managing brand equity in business markets. Industrial Marketing Management, 39(8), 1219-1222. 
Lude, M., \& Prügl, R. (2018). Why the family business brand matters: Brand authenticity and the family firm trust inference. Journal of Business Research, 89, 121-134.

Matear, S., Osborne, P., Garrett, T., \& Gray, B. J. (2002). How does market orientation contribute to service firm performance? An examination of alternative mechanisms. European Journal of Marketing, 36(9/10), 1058-1075.

Memili, E., Eddleston, K. A., Kellermanns, F. W., Zellweger, T. M., \& Barnett, T. (2010). The critical path to family firm success through entrepreneurial risk taking and image. Journal of Family Business Strategy, 1(4), 200-209.

Micelotta, E. R., \& Raynard, M. (2011). Concealing or revealing the family? Corporate brand identity strategies in family firms. Family Business Review, 24(3), 197-216.

Mustakallio, M., Autio, E., \& Zahra, S. A. (2002). Relational and contractual governance in family firms: Effects on strategic decision making. Family Business Review, 15(3), 205222.

Narver, J. C., Slater, S. F., \& MacLachlan, D. L. (2004). Responsive and proactive market orientation and new $\square$ product success. Journal of Product Innovation Management, 21(5), 334-347.

Neubaum, D. (2018). Family business research: Roads travelled and the search for unworn paths. Family Business Review, 31, 259-270.

Neuendorf, K. A. (2016). The content analysis guidebook: Sage publications.

Okoroafo, S. C., \& Koh, A. (2009). The Impact of the Marketing Activities of Family Owned Businesses. International Journal of Business and Management, 4(10), 3-13.

Orth, U. R., \& Green, M. T. (2009). Consumer loyalty to family versus non-family business: The roles of store image, trust and satisfaction. Journal of Retailing and Consumer Services, 16(4), 248-259.

Poza, E. J., Alfred, T., \& Maheshwari, A. (1997). Stakeholder perceptions of culture and management practices in family and family firms-A preliminary report. Family Business Review, 10(2), 135-155.

Presas, P., Muñoz, D., \& Guia, J. (2011). Branding familiness in tourism family firms. Journal of Brand Management, 18(4-5), 274-284.

Punniyamoorthy, M., Mathiyalagan, P., \& Parthiban, P. (2011). A strategic model using structural equation modeling and fuzzy logic in supplier selection. Expert Systems with Applications, 38(1), 458-474. 
Reilly, T. M., \& Jones, R. (2017). Mixed methodology in family business research: Past accomplishments and perspectives for the future. Journal of Family Business Strategy, 8(3), 185-195.

Rönkkö, M., \& Evermann, J. (2013). A critical examination of common beliefs about partial least squares path modeling. Organizational Research Methods, 16(3), 425-448.

Sageder, M., Mitter, C., \& Feldbauer $\square$ Durstmüller, B. (2018). Image and reputation of family firms: a systematic literature review of the state of research. Review of Managerial Science, 12(1), 335-377.

Sarstedt, M., Hair, J. F., Ringle, C. M., Thiele, K. O., \& Gudergan, S. P. (2016). Estimation issues with PLS and CBSEM: Where the bias lies! Journal of Business Research, 69(10), 3998-4010.

Schellong, M., Kraiczy, N. D., Malär, L., \& Hack, A. (2018). Family Firm Brands, Perceptions of Doing Good, and Consumer Happiness. Entrepreneurship Theory and Practice, in press.

Spiggle, S. (1994). Analysis and interpretation of qualitative data in consumer research. Journal of Consumer Research, 21(3), 491-503.

Sundaramurthy, C., \& Kreiner, G. E. (2008). Governing by managing identity boundaries: The case of family businesses. Entrepreneurship Theory and Practice, 32(3), 415-436.

Täuscher, K., \& Laudien, S. M. (2018). Understanding platform business models: A mixed methods study of marketplaces. European Management Journal, 36(3), 319-329.

Tomarken, A. J., \& Waller, N. G. (2003). Potential problems with" well fitting" models. Journal of Abnormal Psychology, 112(4), 578-598.

Van Dun, D. H., Hicks, J. N., \& Wilderom, C. P. (2017). Values and behaviors of effective lean managers: Mixed-methods exploratory research. European Management Journal, 35(2), 174-186.

Vázquez, R., Santos, M. L., \& Álvarez, L. I. (2001). Market orientation, innovation and competitive strategies in industrial firms. Journal of Strategic Marketing, 9(1), 69-90.

Veloutsou, C., \& Taylor, C. S. (2012). The role of the brand as a person in business to business brands. Industrial Marketing Management, 41(6), 898-907.

Verhoef, P. C., \& Leeflang, P. S. (2009). Understanding the marketing department's influence within the firm. Journal of Marketing, 73(2), 14-37.

Welter, F. (2011). Contextualizing entrepreneurship—conceptual challenges and ways forward. Entrepreneurship Theory and Practice, 35(1), 165-184. 
Zellweger, T. M., Eddleston, K. A., \& Kellermanns, F. W. (2010). Exploring the concept of familiness: Introducing family firm identity. Journal of Family Business Strategy, 1(1), 54-63.

Zellweger, T. M., Kellermanns, F. W., Eddleston, K. A., \& Memili, E. (2012). Building a family firm image: How family firms capitalize on their family ties. Journal of Family Business Strategy, 3(4), 239-250.

Zellweger, T. (2017). Managing the family business: Theory and practice. Edward Elgar Publishing. 


\section{Appendix}

Appendix A: Interview guideline (study 1)

\section{Selected interview questions}

\section{General questions}

What does your firm distinguish from other firms within the market?

How do you define brand management?

How do you describe the brand management of your firm?

Do you differentiate between the brand management of products and the entire company?

Have you specified certain associations that you strive to provoke in the customer's mind through your brand?

How important is brand management to you? Where do you primarily focus on, either internally or externally?

To what degree do you regard your brand management as successful?

What factors contribute to the success of your brand management?

How does your brand management differ from competitors?

How does your brand management differ from other family firms?

\section{Research specific questions}

How important is being a family firm to you in terms of brand management and why?

When and why is the communication of the family nature of the firm of advantage?

When and why is the communication of the family nature of the firm of disadvantage?

Which role does your family play within your branding strategy?

Which family firms do you consider having a remarkably good or bad brand management and for what reason?

How did you personally change the brand management of your firm and for what reason? 
Appendix B: Operationalization of constructs in study 2

\begin{tabular}{|c|c|c|c|}
\hline $\begin{array}{l}\text { Type of } \\
\text { Variable }\end{array}$ & Construct & Items & Source \\
\hline \multirow[t]{10}{*}{ IV } & $\begin{array}{l}\text { Innovation } \\
\text { intensity of } \\
\text { the industry } \\
(\mathrm{AVE}=.680 \\
\mathrm{CR}=.894)\end{array}$ & $\begin{array}{l}\text { Products and services are changing at a very fast pace in } \\
\text { our industry. } \\
\text { Compared to other indstries, innovations in our industry } \\
\text { get introduced at a very fast pace. } \\
\text { I have not seen significantly new products and services } \\
\text { for sometime (reverse-coded). } \\
\text { Innovations in our industry are very frequent. } \\
\text { Pace of innovations within our industry is high. }\end{array}$ & $\begin{array}{l}\text { Adapted from Grewal, } \\
\text { Mehta, and Kardes } \\
\text { (2004) }\end{array}$ \\
\hline & $\begin{array}{l}\text { FFs as } \\
\text { competitors }\end{array}$ & $\begin{array}{l}\text { What statement fits your competitors structure? } \\
\text { (1=family firms are a minority; } 2=\text { equal distribution; } \\
\text { 3=family firms are a majority) }\end{array}$ & $\begin{array}{l}\text { Adapted from } \\
\text { Anderson and Reeb } \\
(2003)\end{array}$ \\
\hline & Sector & $\begin{array}{l}\text { In what sector are you primarily with your business? }(1= \\
\text { B2B; } 2=\text { both: } 3=\mathrm{B} 2 \mathrm{C})\end{array}$ & $\begin{array}{l}\text { Adopted from Botero, } \\
\text { Thomas, Graves, and } \\
\text { Fediuk (2013) }\end{array}$ \\
\hline & Firm size & $\begin{array}{l}\text { How many employees are currently working in your } \\
\text { family firm? }\end{array}$ & $\begin{array}{l}\text { Claver, Rienda, and } \\
\text { Quer (2009) }\end{array}$ \\
\hline & $\begin{array}{l}\text { International } \\
\text { ization }\end{array}$ & $\begin{array}{l}\text { In how many markets (countries) are you currently } \\
\text { operating? (open) }\end{array}$ & $\begin{array}{l}\text { Adapted from } \\
\text { Allayannis, Thrig, and } \\
\text { Weston (2001) }\end{array}$ \\
\hline & $\begin{array}{l}\text { FFs as } \\
\text { partners }\end{array}$ & $\begin{array}{l}\text { What statement fits your business partner structure? } \\
\text { (1=FFs are a minority; } 2=\text { equal distribution; } 3=F F \text { are a } \\
\text { majority) }\end{array}$ & $\begin{array}{l}\text { Adapted from } \\
\text { Anderson and Reeb } \\
(2003)\end{array}$ \\
\hline & $\begin{array}{l}\text { Probability } \\
\text { of family } \\
\text { succession }\end{array}$ & $\begin{array}{l}\text { How probable do you consider that the next family } \\
\text { generation will take over the family business? }\end{array}$ & $\begin{array}{l}\text { Adopted frm Poza, } \\
\text { Alfred, and } \\
\text { Maheshwari (1997) } \\
\text { and Chua, Chrisman, } \\
\text { and Sharma (2003) }\end{array}$ \\
\hline & $\begin{array}{l}\text { Family } \\
\text { influence on } \\
\text { marketing }\end{array}$ & $\begin{array}{l}\text { Please indicate who influences to a stronger degree the } \\
\text { marketing decisions ( }-3=\text { non-family members; } 0=\text { equal } \\
\text { influence; }+3=\text { family members) }\end{array}$ & $\begin{array}{l}\text { Adapted form Verhoef } \\
\text { and Leeflang (2009) } \\
\text { and Mustakallio, } \\
\text { Autio, and Zahra } \\
(2002)\end{array}$ \\
\hline & $\begin{array}{l}\text { Tradition } \\
\text { orientation } \\
\text { (AVE=.562 } \\
\mathrm{CR}=.899 \text { ) }\end{array}$ & $\begin{array}{l}\text { Family firms should act in line with their long-term } \\
\text { tradition. } \\
\text { Firms with a strong tradition have advantages in terms of } \\
\text { recruiting personnel. } \\
\text { Firms with a strong tradition will be appreciated even } \\
\text { more in the future. } \\
\text { Firms with a strong tradition are able to handle } \\
\text { challenges arising from a unsteady and fast-moving } \\
\text { society. } \\
\text { We corporate goals are linked to our traditions. } \\
\text { Our competitive advantage arises from our tradition. } \\
\text { We are more aware of our traditions then our } \\
\text { competitors. }\end{array}$ & $\begin{array}{l}\text { Adopted from } \\
\text { Kuckertz and Wagner } \\
(2010) \text { and Deshpandé } \\
\text { and Farley (1998) }\end{array}$ \\
\hline & $\begin{array}{l}\text { Innovation } \\
\text { orientation } \\
(\mathrm{AVE}=.558 \\
\mathrm{CR}=.858)\end{array}$ & $\begin{array}{l}\text { The management actively seeks innovative ideas. } \\
\text { Innovation in our company is perceived as too risky and } \\
\text { is resisted. } \\
\text { Competitors in this market recognize us as innovation } \\
\text { leaders. } \\
\text { We are recognized for being at the leading edge of } \\
\text { technological innovation. } \\
\text { We are first to market with new products or services. }\end{array}$ & $\begin{array}{l}\text { Adopted from Narver, } \\
\text { Slater, and } \\
\text { MacLachlan (2004) } \\
\text { and Vázquez, Santos, } \\
\text { and Álvarez (2001) }\end{array}$ \\
\hline
\end{tabular}


Appendix B (continued): Operationalization of constructs in study 2

\begin{tabular}{|c|c|c|c|}
\hline $\begin{array}{l}\text { Type of } \\
\text { variable }\end{array}$ & Construct & Items & Source \\
\hline IV & $\begin{array}{l}\text { Extraversion } \\
(\mathrm{AVE}=.579 \\
\mathrm{CR}=.803)\end{array}$ & $\begin{array}{l}\text { I easily approach strangers. } \\
\text { I like to talk with others. } \\
\text { I am optimistic. } \\
\text { Nobody likes talking with } \\
\text { me. }\end{array}$ & $\begin{array}{l}\text { Adopted from } \\
\text { de Vries (2013) }\end{array}$ \\
\hline \multirow[t]{2}{*}{ DV } & $\begin{array}{l}\text { Degree to } \\
\text { promote the } \\
\text { family firm } \\
\text { status } \\
(\mathrm{AVE}=.472 \\
\mathrm{CR}=.815)\end{array}$ & $\begin{array}{l}\text { The family firm name is recognized in the community. } \\
\text { The family name is used as brand. } \\
\text { In our advertisement, we mention that we are a family } \\
\text { business. } \\
\text { Most of our customers know that we are a family business. } \\
\text { The fact that we are a family business is a great marketing } \\
\text { tool. }\end{array}$ & $\begin{array}{l}\text { Adopted from } \\
\text { Memili, } \\
\text { Eddleston, } \\
\text { Kellermanns, } \\
\text { Zellweger, and } \\
\text { Barnett (2010) }\end{array}$ \\
\hline & $\begin{array}{l}\text { Brand } \\
\text { performance } \\
(\mathrm{AVE}=.530 \\
\mathrm{CR}=.848)\end{array}$ & $\begin{array}{l}\text { Compared to your main competitor, how satisfied are you } \\
\text { with your } \\
\ldots \text { customer satisfaction? } \\
\ldots \text { customer loyalty? } \\
\ldots \text { brand awareness? } \\
\ldots \text { brand value? } \\
\ldots \text { corporate reputation? }\end{array}$ & $\begin{array}{l}\text { Adopted from } \\
\text { Matear, } \\
\text { Osborne, } \\
\text { Garrett, and } \\
\text { Gray (2002) }\end{array}$ \\
\hline \multirow[t]{6}{*}{$\mathbf{C V}$} & $\begin{array}{l}\text { Generational } \\
\text { stage }\end{array}$ & $\begin{array}{l}\text { What is the number of the current generation leading this } \\
\text { company (open) }\end{array}$ & $\begin{array}{l}\text { Adapted form } \\
\text { Mustakallio et } \\
\text { al. (2002) }\end{array}$ \\
\hline & $\begin{array}{l}\text { Family } \\
\text { members in } \\
\text { the } \\
\text { management } \\
\text { board }\end{array}$ & $\begin{array}{l}\text { How many family members (you included) are currently } \\
\text { working in the management board? (open) }\end{array}$ & $\begin{array}{l}\text { Adapted form } \\
\text { Mustakallio et } \\
\text { al. (2002) }\end{array}$ \\
\hline & $\begin{array}{l}\text { Family } \\
\text { members } \\
\text { employed in } \\
\text { the company }\end{array}$ & $\begin{array}{l}\text { How many family members (you included) are currently } \\
\text { working in the company? (open) }\end{array}$ & $\begin{array}{l}\text { Adapted from } \\
\text { Mustakallio et } \\
\text { al. (2002) and } \\
\text { Chua et al. } \\
\text { (2003) }\end{array}$ \\
\hline & Founding year & In what year was the family firm founded? (open) & $\begin{array}{l}\text { Adopted from } \\
\text { Chrisman, } \\
\text { Chua, and Litz } \\
(2004)\end{array}$ \\
\hline & $\begin{array}{l}\text { Influence of } \\
\text { external } \\
\text { marketing } \\
\text { consultancy }\end{array}$ & $\begin{array}{l}\text { Who has mainly created the concept for your brand } \\
\text { management? (1=external marketing consultancy; } \\
2=\text { marketing department; } 3=\text { non-family members in top } \\
\text { management; } 4=\text { family members in top management; } \\
\text { others) }\end{array}$ & $\begin{array}{l}\text { Adapted from } \\
\text { Chua et al. } \\
\text { (2003) }\end{array}$ \\
\hline & $\begin{array}{l}\text { Family } \\
\text { ownership }\end{array}$ & $\begin{array}{l}\text { How is the ownership distributed? } \\
\text { ( \% of family ownership) }\end{array}$ & $\begin{array}{l}\text { Adopted from } \\
\text { Memili et al. } \\
\text { (2010) }\end{array}$ \\
\hline
\end{tabular}

Note: $\mathrm{FF}=$ family firm; IV=independent variable, $\mathrm{DV}=$ dependent variable, $\mathrm{CV}=$ control variable; $\mathrm{AVE}=$ average variance extracted (only displayed if applicable); $\mathrm{CR}=$ composite reliability (only displayed if applicable)

If not otherwise indicated responses were assessed on a 7-point Likert-type scale ranging from 1=I do not agree at all; $7=$ I fully agree). 


\section{Figures}

Figure 1: Overview of two subsequent studies (exploratory sequential mixed methods design)

\begin{tabular}{|c|c|c|c|}
\hline \multicolumn{4}{|c|}{ What are the antecedents of the managerial decision regarding the degree to which a family firm image is communicated? } \\
\hline & $\begin{array}{c}\text { Study } 1 \\
\text { (qualitative) }\end{array}$ & \multicolumn{2}{|l|}{$\begin{array}{c}\text { Study } 2 \\
\text { (quantitative) }\end{array}$} \\
\hline Approach & $\begin{array}{c}\text { Exploratory } \\
\text { (expert interviews \& literature) }\end{array}$ & $\begin{array}{l}\text { Explanatory } \\
\text { (survey data) }\end{array}$ & $\begin{array}{l}\text { Exploratory (survey } \\
+ \text { secondary data) }\end{array}$ \\
\hline Aim & Development of hypotheses & Testing of hypotheses of Study 1 & $\begin{array}{l}\text { Explore performance } \\
\text { consequences }\end{array}$ \\
\hline $\begin{array}{l}\text { Dependent } \\
\text { Variable }\end{array}$ & $\begin{array}{c}\text { Family Firm Image: The degree to } \\
\text { which a family firm image is } \\
\text { communicated } \\
\text { (3 degrees, Micelotta \& Raynard, 2011) }\end{array}$ & $\begin{array}{l}\text { Family Firm Image: The degree to } \\
\text { which a family firm image is } \\
\text { communicated } \\
\text { (Continuous measure, Memili et al., 2010) }\end{array}$ & $\begin{array}{l}\text { Subjective brand } \\
\text { performance \& } \\
\text { objective sales data }\end{array}$ \\
\hline
\end{tabular}

Figure 2: Overview of the data structure (analysis procedure adapted from Kotlar and De Massis, 2013)

\begin{tabular}{|c|c|c|c|}
\hline First-order Factors & \multirow{3}{*}{$\longrightarrow$} & Second-order Themes & Aggregate Dimensions \\
\hline Innovation intensity of the industry & & \multirow{2}{*}{ Industry structure } & \multirow{2}{*}{ Environment } \\
\hline Family firms as competitors & & & \\
\hline $\mathrm{B} 2 \mathrm{C} / \mathrm{B} 2 \mathrm{~B}$ sector & $\longrightarrow$ & \multirow{2}{*}{ Firm characteristics } & \multirow{3}{*}{ Business } \\
\hline Firm size & $\longrightarrow$ & & \\
\hline Degree of internationalization & $\rightarrow$ & \multirow{2}{*}{ Corporate strategy } & \\
\hline Family firms as business partners & $\longrightarrow$ & & \\
\hline Probability of family succession & $\rightarrow$ & \multirow{2}{*}{ Family involvement } & \\
\hline Family influence on marketing & $\longrightarrow$ & & \\
\hline Tradition orientation & $\longrightarrow$ & \multirow{2}{*}{ Family focus } & \multirow{3}{*}{ Family } \\
\hline Innovation orientation & $\longrightarrow$ & & \\
\hline Extraversion of family CEO & $\longrightarrow$ & Family leadership & \\
\hline
\end{tabular}


Figure 3: Conceptual model derived in study 1 and tested in study 2

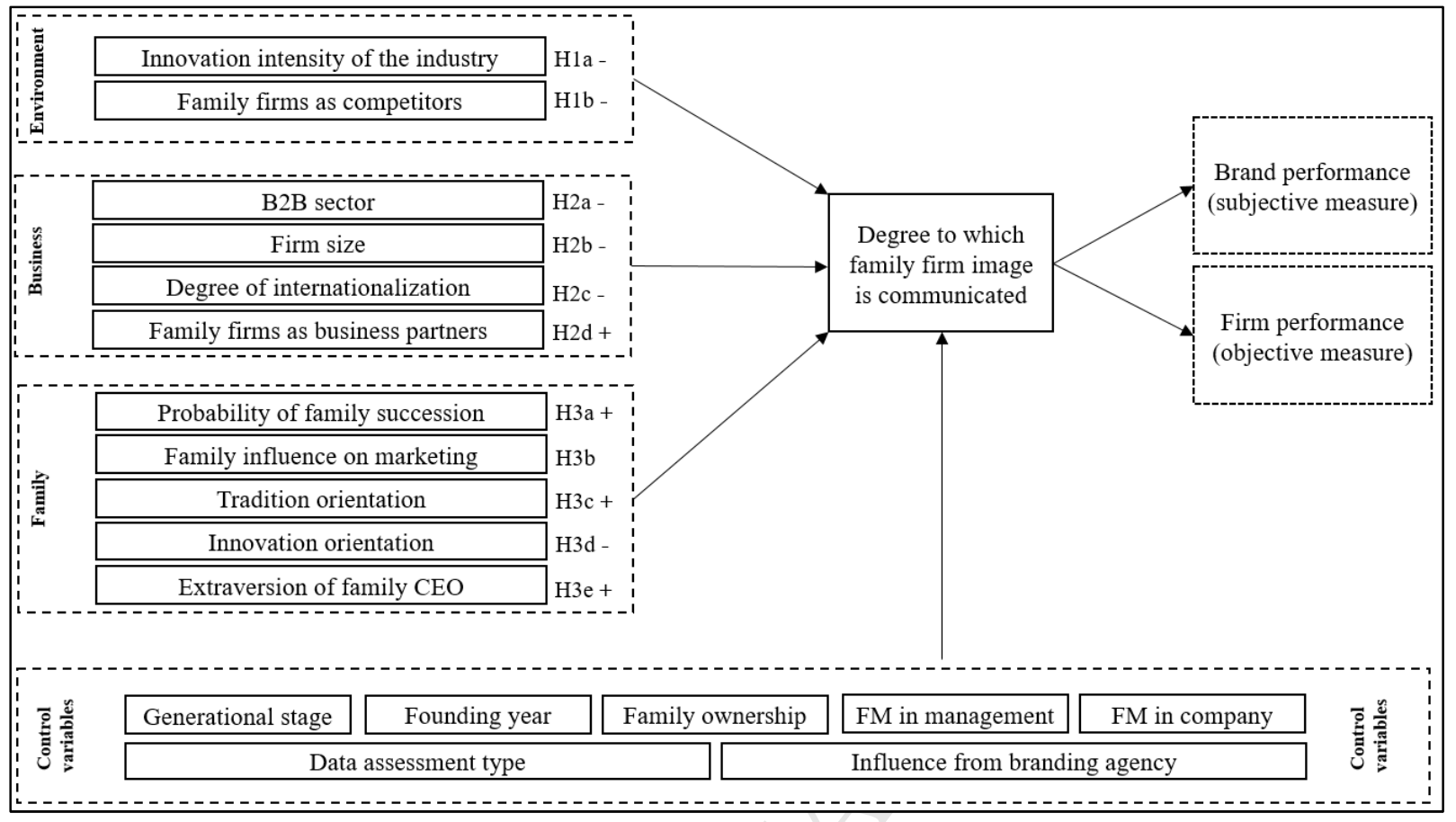

Figure 4: Results of study 2

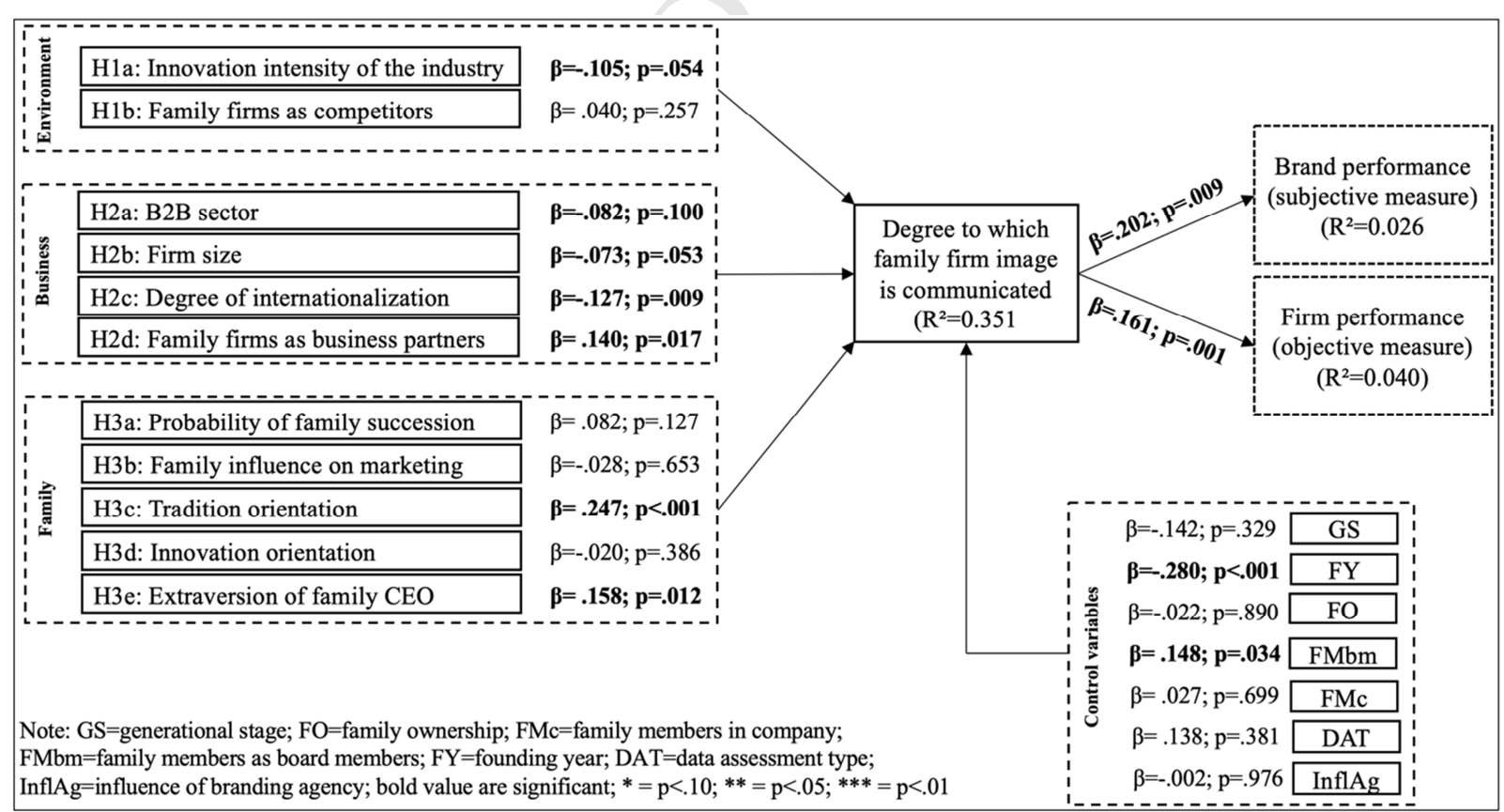




\section{Tables}

Table 1: Literature review on family firm identity and family firm image

\begin{tabular}{ll}
\hline Authors & Main findings/conclusions \\
\hline $\begin{array}{l}\text { Binz } \\
\text { Astrachan and }\end{array}$ & $\begin{array}{l}\text { Identity-related motives, e.g., pride of the family achievements and } \\
\text { identification with the company, and outcome-related motives improving } \\
\text { the reputation are identified as main drivers of the communication of the } \\
\text { family firm status. However, the degree of disclosure would remain } \\
\text { restricted in case that the family reputation was weakened or even } \\
\text { harmed. }\end{array}$ \\
$\begin{array}{l}\text { Blombäck and } \\
\text { Brunninge }\end{array}$ & $\begin{array}{l}\text { Family firms having a dual source of identity (firm, family) can leverage } \\
\text { their brand heritage and can thus shape their corporate image in multiple } \\
\text { ways. Thereby, family firms may benefit from several potential strengths: }\end{array}$ \\
& longevity, track record, core values, symbols, and history.
\end{tabular}

Type/context of research

Qualitative

study/Germany

and Switzerland

Blombäck and Family firms showing a high level of family firm image aim at creating a Brunninge corporate reputation of authenticity, high quality, reliability and stability, (2016) as well as strong and long-lasting values.

Blombäck and The creation of the family firm image is the result of three simultaneous Ramírez- processes: intuitive, emergent and strategic.

Pasillas (2012)

Botero et al. Family firms have multiple identities, among them: actual, (2013) communicated, conceived, ideal, and desired identity. The study of family firm websites shows that $43 \%$ of the firms do not promote their family firm identity, and thus do not use a family firm image.

Craig et al. The promotion of the family firm image has an indirect positive effect on (2008) firm performance by rising the customer-centric orientation.

Quantitative study/US

Gallucci et al. A family firm image moderates the relationship between family (2015) involvement and sales growth.

Quantitative study/Italy

Kashmiri and Family firms communicating a family firm image as part of their branding Mahajan strategy score higher on corporate citizenship, representations of (2010) customers' voice, and strategic emphasis and thus perform better.

Kashmiri and Family firms revealing the family firm identity enjoy fewer cases of Mahajan product-related deficiencies when introducing new products, particularly (2014) in case that the familial influence is high.

Memili et al. The family firm identity (family ownership, family expectations) (2010) positively influences the usage of the family firm image.

Quantitative study/US

Quantitative study/US

Quantitative study/Switzerland

Micelotta and Family firms vary in the extent to communicate their family firm image. Raynard The study of family firm websites reveals three branding strategies (2011) (family preservation, enrichment, subordination) that differ in three dimensions (carrier of identity, temporality, and role of the family).

Qualitative study/Across continents accept Australia

Presas et al. The family firm identity is the basis of the corporate brand and is thus (2011) inherent in the strategic vision, organizational culture and corporate Case study/Spain image.

Zellweger et Family pride, community social ties and long-term orientation enhance al. (2012) the development of a family firm identity.

Quantitative study/Switzerland 
Table 2: Firm and interview specifications

\begin{tabular}{|c|c|c|c|c|c|c|c|c|c|c|}
\hline \multirow[t]{2}{*}{ Firm } & \multicolumn{6}{|l|}{ Firm information } & \multicolumn{4}{|c|}{ Interview information } \\
\hline & $\begin{array}{l}\text { Degree of } \\
\text { communication of } \\
\text { Family firm image }\end{array}$ & $\begin{array}{l}\text { Founding } \\
\text { Year } \\
\text { (app.) }\end{array}$ & $\begin{array}{l}\text { Gene- } \\
\text { ration }\end{array}$ & $\begin{array}{l}\text { No. of } \\
\text { employees } \\
\text { (app.) }\end{array}$ & Sector & Industry & $\begin{array}{l}\text { No. of } \\
\text { interviews }\end{array}$ & $\begin{array}{l}\text { Inter- } \\
\text { generational } \\
\text { position }\end{array}$ & $\begin{array}{l}\text { Current } \\
\text { role }\end{array}$ & $\begin{array}{l}\text { Duration } \\
\text { (minutes) }\end{array}$ \\
\hline $\mathbf{P} 2$ & $\begin{array}{l}\text { High (family } \\
\text { preservation) }\end{array}$ & 1950 & 3 & 70 & $\mathrm{~B} 2 \mathrm{C}$ & Bakery products & 1 & Predecessor & $\begin{array}{l}\text { Former } \\
\text { CEO }\end{array}$ & $67: 51$ \\
\hline E2 & $\begin{array}{l}\text { Medium (family } \\
\text { enrichment) }\end{array}$ & 1840 & 6 & 500 & $\begin{array}{l}\mathrm{B} 2 \mathrm{C} / \\
\mathrm{B} 2 \mathrm{~B}\end{array}$ & Snacks & 1 & Incumbent & $\mathrm{CEO}$ & $73: 23$ \\
\hline $\mathbf{E 3}$ & $\begin{array}{l}\text { Medium (family } \\
\text { enrichment) }\end{array}$ & 1910 & 3 & 80 & $\begin{array}{l}\mathrm{B} 2 \mathrm{C} / \\
\mathrm{B} 2 \mathrm{~B}\end{array}$ & Jams and Jellies & 1 & Incumbent & CEO & $76: 50$ \\
\hline $\mathbf{E 4}$ & $\begin{array}{l}\text { Medium (family } \\
\text { enrichment) }\end{array}$ & 1920 & 3 & 250 & $\mathrm{~B} 2 \mathrm{C}$ & Health care & 1 & Incumbent & TMT & $63: 37$ \\
\hline S1 & $\begin{array}{l}\text { Low (family } \\
\text { subordination) }\end{array}$ & 1530 & 14 & 2,300 & B2B & $\begin{array}{l}\text { Glass } \\
\text { manufacturing }\end{array}$ & 2 & $\begin{array}{l}\text { Incumbent \& } \\
\text { successor }\end{array}$ & $\begin{array}{l}\text { CEO \& } \\
\text { TMM }\end{array}$ & $\begin{array}{l}29: 57 / \\
42: 51\end{array}$ \\
\hline S2 & $\begin{array}{l}\text { Low (family } \\
\text { subordination) }\end{array}$ & 1925 & 3 & 800 & B2B & Prosthetic dentistry & 2 & $\begin{array}{l}\text { Incumbent \& } \\
\text { successor }\end{array}$ & $\begin{array}{l}\text { CEO \& } \\
\text { TMM }\end{array}$ & $91: 20$ \\
\hline
\end{tabular}

Note: The letters used for firm numbering refer to the according brand strategy. Thus, S1 refers to a firm applying subordination strategy. In the same vein, E1 (P1) refers to the enrichment (preservation) strategy. $\mathrm{CEO}=\mathrm{Chief}$ executive officer. TMM=Top management team member. Founding years and amounts of employees have been rounded to allow for anonymity of the interviewed companies. 
Table 3: Summary of hypotheses derived from study 1

\begin{tabular}{ll}
\hline $\begin{array}{l}\text { Antecedent } \\
\text { (hypothesized } \\
\text { relation) }\end{array}$ & Hypothesis \\
\hline $\begin{array}{l}\text { Innovation } \\
\text { intensity (-) }\end{array}$ & $\begin{array}{l}\text { 1a: The higher the } \\
\text { innovation intensity of an } \\
\text { industry, the less a family } \\
\text { firm communicates a family } \\
\text { firm image. }\end{array}$
\end{tabular}

Family firms 1b: The more family firms as among its competitors, the competitors less a family firm (-) communicates a family firm image.

B2B sector (-) 2a: A family firm operating in the B2B sector is less likely to communicate a family firm image (compared to family firms in the $\mathrm{B} 2 \mathrm{C}$ sector).

Firm size (-) 2b: The larger a family firm is, the less it communicates a family firm image.

$\begin{array}{ll}\text { Degree of } & \text { 2c: The more a family firm } \\ \text { internation- } & \text { operates internationally, the } \\ \text { alization (-) } & \begin{array}{l}\text { less it communicates a } \\ \text { family firm image. }\end{array}\end{array}$

Family firms as business partners (+)

\section{Exemplary statements}

Firm S2: The slogan [of another exemplary company] implicates (...), that the quality used to be much better in the past. (...) These are industries (...), in which one can leverage the family album. (...) But this is a different form of communication.

Firm P2: But where are nowadays products, that are older than 20, 25 or even 30 years? (...) You can search a long time for them.

Firm S1: I definitely say that the family values stand out, as they set us apart from the others in the branch.

Firm S2: There are several [family firms] in our industry. (...) Hence, it [the family firm image] does not serve as criteria for differentiation.

Firm E3: If you are a family firm, you always have a story to tell and a way to distinguis h from your competitors.

Firm S1: But we do not offer the typical end-consumer product.

Firm S2: I believe, that it depends on the sector and the customers, whether it [a company] is (publicly) a family firm. (...) But it [marketing with a personal touch] does not make sense for our products.

Firm E4: The people, employees and patients, have adored her [my mother-in-law].

Firm S2: Well, our jubilee of 90 years may be celebrated, but does that make sense? This is the typical age of a grandmother being desperate for help.

Firm E3: In the coffee unit, we try to (...) differentiate our business from large coffee roasters. Thus, being a family firm is highly important.

Firm P1: I would not at all consider us as Mittelstand. We are a small business. (...) Rather a family firm.

Firm: S2: Well, there are actually no companies, that can exclusively concentrate on the German market. (...) Hence, it [the family firm image] does not serve as criteria for differentiation in international business.

Firm E3: It is indeed a family firm [referring to another exemplary company], but actually it is a global player. Hence, there is no differentiation through it [the family firm image].

Firm P1: Nowadays, the topic regionality is highly important and family.

Firm S2: We experience, that our organizational structure facilitates the dealings with classic, small craft businesses compared to huge corporations.

Firm E2: Our suppliers scrutinize, to whom they deliver their goods, they are partially also, let's say, companies with great tradition.

Firm E3: Especially people, who have a family business on their own and sit on the other side of the table, extremely value it [that we are a family firm]. 
Table 3 (continued): Summary of hypotheses derived from study 1

\begin{tabular}{ll}
\hline $\begin{array}{l}\text { Antecedent } \\
\text { (hypothesized } \\
\text { relation) }\end{array}$ & Hypothesis \\
\hline $\begin{array}{l}\text { Probability of } \\
\text { succession (+) }\end{array}$ & $\begin{array}{l}\text { 3a: The lower the } \\
\text { probability of family- } \\
\text { internal succession, the less } \\
\text { a family firm communicates } \\
\text { a family firm image. }\end{array}$ \\
$\begin{array}{l}\text { Family } \\
\text { influence on } \\
\text { marketing } \\
\text { (non- }\end{array}$ & $\begin{array}{l}\text { 3b: The influence of family } \\
\text { members on marketing } \\
\text { afrectional) }\end{array}$ \\
$\begin{array}{l}\text { communicating a family } \\
\text { firm image. }\end{array}$
\end{tabular}

\section{Exemplary statements}

Firm E4: The risk of family firms is the probable lack of a family successor so that the firm must be sold leading to a rupture [regarding the brand].

Firm P2: This [brand] is the tradition, the family and the continuity that results from the family. My son, the third generation, and granddaughter are already ready. (...) This is not something to be taken for granted.

Firm S1: I am not involved in the marketing strategy. Our key account managers made up their minds and told me and my fiancée to attend dinners together to bring the family values into the foreground.

Firm S2: Well, we got 90 years old this year. Our marketing department wanted to celebrate this greatly. We were both unsure, to which extent to celebrate it. (...) This is the typical age of a grandmother being desperate for help.

Firm P1: It is important for a down-to-earth and familial brand, that the wishes and ideas of the family and owners are incorporated. (...) It can be frustrating for [marketing] employees, when the owner has to set some boundaries.

$3 \mathrm{c}$ : The more the owning family focuses on tradition, the more it communicates a family firm image.
$(+)$

Innovation orientation (-)

Extraversion (+) 3d: The more the owning family focuses on innovation, the less it communicates a family firm image.

3e: The more extraverted a family CEO is, the more a family firm communicates a family firm image.
Firm S1: You have to pay attention, that you do not appear to be dusty, too traditional and outdated.

Firm S2: I love to let the grandfather generation tell stories of the war. But this has nothing to do in the professional context. It does not get you anywhere.

Firm E1: Yes, we draw upon tradition and use it in symbiosis with technology.

Firm E3: Following the tradition, the majority of fruits, that E3 manufactures, are even today grown and harvested here in [this region].

Firm E4: We have always been proud and aware of embodying a tradition and we want the name [to communicate the family name].

Firm S1: For instance, on our business cards, you can find the "family [family firm] since $X Y$ " and $a Q R$ code with all information of the card. We designed it on purpose like this to communicate the long-standing tradition as well as something modern.

Firm E1: It [our innovative approach] is definitely at the expense of traditional values. (...) I don't like this dissociation [of family firm and innovativeness].

Firm P2: We have to pay attention [with our brand] not to be perceived being too far in advance of the times.

Firm S2: We are not the ones, who promote in video clips: "These are my teeth and for them I stand with my name". We don't do that. I am not that kind of person.

Firm E2: Of course, you don't hide away as entrepreneur. (...) But it is not as if I were an active brand ambassador. That is not me.

Firm E4: We have to become well-known [as a family] and leave a mark in the press.

Firm P2: They interviewed me for two hours, whereof they showed 15 minutes on TV. They also interviewed my son, which was great. (...) I received so many calls.

Note: Squared brackets indicate remarks made by authors for clarification purposes. 
Table 4: Sample of the quantitative study 2

\begin{tabular}{lllll}
\hline Characteristic & Min & Max & Mean & SD \\
\hline Founding year & 1830 & 2005 & 1962 & 38.174 \\
Generational stage & 1 & $>4$ & N/A & N/A \\
Number of employees & 10 & 1625 & 113.6 & 196.062 \\
FM in company & 0 & 8 & 2.7 & 1.688 \\
FM as board members & 1 & 6 & 1.8 & 0.973 \\
\% of family ownership & 50 & 100 & 99.5 & 13.883 \\
\hline
\end{tabular}

$\mathrm{N}=196$; Note: $\mathrm{FM}=$ family members

Table 5: Results of PLS-SEM model

\begin{tabular}{|c|c|c|c|c|c|}
\hline $\begin{array}{l}\text { Variable } \\
\text { Group }\end{array}$ & Path & $\begin{array}{l}\text { Std. path } \\
\text { coefficient }\end{array}$ & $\begin{array}{c}\text { Std. } \\
\text { deviation }\end{array}$ & $\begin{array}{c}\mathrm{t}- \\
\text { Statistics } \\
\end{array}$ & p-value \\
\hline \multirow{3}{*}{$\begin{array}{l}\text { Hypothesized } \\
\text { antecedents: }\end{array}$} & H1a: Innovation Intensity $\rightarrow$ FFI & $-0.105^{*}$ & 0.065 & 1.611 & 0.054 \\
\hline & H1b: FFs as competitors $\rightarrow$ FFI & 0.040 & 0.062 & 0.652 & 0.257 \\
\hline & H2a: B2B Sector $\rightarrow$ FFI & $-0.082 *$ & 0.064 & 1.283 & 0.100 \\
\hline \multirow{3}{*}{$\begin{array}{l}\text { Environment } \\
\text { (H1a, b) }\end{array}$} & H2b: Firm size $\rightarrow$ FFI & $-0.073^{*}$ & 0.045 & 1.622 & 0.053 \\
\hline & H2c: Internationalization $\rightarrow$ FFI & $-0.127 * * *$ & 0.053 & 2.392 & 0.009 \\
\hline & $\mathrm{H} 2 \mathrm{~d}$ : FFs as business partners $\rightarrow$ FFI & $0.140 * *$ & 0.066 & 2.132 & 0.017 \\
\hline \multirow{2}{*}{$\begin{array}{l}\text { Business } \\
\text { (H2a-d) }\end{array}$} & H3a: Prob. family succession $\rightarrow$ FFI & 0.082 & 0.072 & 1.141 & 0.127 \\
\hline & $\mathrm{H} 3 \mathrm{~b}: \mathrm{FI}$ on marketing $\rightarrow$ FFI & -0.028 & 0.062 & 0.450 & 0.653 \\
\hline \multirow{3}{*}{$\begin{array}{l}\text { Family } \\
\text { (H3a-e) }\end{array}$} & H3c: Tradition orientation $\rightarrow$ FFI & $0.247 * * *$ & 0.060 & 4.088 & 0.000 \\
\hline & H3d: Innovation orientation $\rightarrow$ FFI & 0.020 & 0.067 & 0.291 & 0.386 \\
\hline & H3e: Extraversion family CEO $\rightarrow$ FFI & $0.158 * *$ & 0.069 & 2.276 & 0.012 \\
\hline \multirow{2}{*}{$\begin{array}{l}\text { Performance } \\
\text { measures }\end{array}$} & FFI $\rightarrow$ Firm performance & $0.161 * * *$ & 0.053 & 3.066 & 0.001 \\
\hline & FFI $\rightarrow$ Brand performance & $0.202 * * *$ & 0.085 & 2.372 & 0.009 \\
\hline \multirow[t]{7}{*}{ Controls } & Generational stage $\rightarrow$ FFI & -0.142 & 0.146 & 0.977 & 0.329 \\
\hline & Founding year $\rightarrow$ FFI & $-0.280 * * *$ & 0.069 & 4.038 & 0.000 \\
\hline & Family ownership $\rightarrow$ FFI & -0.022 & 0.162 & 0.138 & 0.890 \\
\hline & FM as board members $\rightarrow$ FFI & $0.148 * *$ & 0.069 & 2.124 & 0.034 \\
\hline & FM in company $\rightarrow$ FFI & 0.027 & 0.071 & 0.387 & 0.699 \\
\hline & Data assessment type $\rightarrow$ FFI & 0.138 & 0.158 & 0.876 & 0.381 \\
\hline & Influence of branding agency $\rightarrow$ FFI & -0.002 & 0.065 & 0.030 & 0.976 \\
\hline
\end{tabular}

Note: FFI = family firm image (scale from Memili et al., 2010); Firm size $=$ number of employees, FF=family firm, FI=family influence; FM=family member; $\mathrm{p}$-value is one-sided for directional hypotheses and two-sided for undirected hypotheses and controls; T-statistics are derived from a bootstrapping procedure with 2,000 subsamples; Significance levels: $*=\mathrm{p}<.10 ; * *=\mathrm{p}<.05 ; * * *=\mathrm{p}<.01$ 
Table 1: Literature review on family firm identity and family firm image

\begin{tabular}{|c|c|}
\hline Authors & Main findings/conclusions \\
\hline $\begin{array}{l}\text { Binz } \\
\text { Astrachan and } \\
\text { Botero (2017) }\end{array}$ & $\begin{array}{l}\text { Identity-related motives, e.g., pride of the family achievements and } \\
\text { identification with the company, and outcome-related motives } \\
\text { improving the reputation are identified as main drivers of the } \\
\text { communication of the family firm status. However, the degree of } \\
\text { disclosure would remain restricted in case that the family reputation was } \\
\text { weakened or even harmed. }\end{array}$ \\
\hline $\begin{array}{l}\text { Blombäck and } \\
\text { Brunninge } \\
\text { (2013) }\end{array}$ & $\begin{array}{l}\text { Family firms having a dual source of identity (firm and family) can } \\
\text { leverage their brand heritage and can thus shape their corporate image } \\
\text { in multiple ways. Thereby, family firms may benefit from several } \\
\text { potential strengths: longevity, track record, core values, symbols, and } \\
\text { history. }\end{array}$ \\
\hline
\end{tabular}

Type/context of research

Qualitative

study/Germany

and Switzerland

Blombäck and Family firms showing a high level of family firm image aim at creating Brunninge a corporate reputation of authenticity, high quality, reliability, and (2016) stability, as well as strong and long-lasting values.

Blombäck and The creation of the family firm image is the result of three simultaneous RamírezPasillas (2012) processes: intuitive, emergent, and strategic.

Botero et al. Family firms have multiple identities, among them: actual, (2013) communicated, conceived, ideal, and desired identity. The study of family firm websites shows that $43 \%$ of the firms do not promote their family firm identity, and thus do not use a family firm image.

Craig et al. The promotion of the family firm image has an indirect positive effect (2008) on firm performance by raising the customer-centric orientation.

Gallucci et al. A family firm image moderates the relationship between family (2015) involvement and sales growth.

Conceptual paper/-

Qualitative study/Sweden

Qualitative study/Sweden

Quantitative study/Australia, US, UK

Quantitative study/US

Quantitative study/Italy

Quantitative study/US branding strategy score higher on corporate citizenship, representations of customers' voice, and strategic emphasis and thus perform better.

Mahajan

(2010)

Kashmiri and Mahajan

Memili et al. (2010)

Family firms revealing the family firm identity enjoy fewer cases of product-related deficiencies when introducing new products, particularly in case that the familial influence is high.

Micelotta and Raynard (2011)

The family firm identity (family ownership and family expectations) positively influences the usage of the family firm image.

Family firms vary in the extent to communicate their family firm image. The study of family firm websites reveals three branding strategies (family preservation, enrichment, and subordination) that differ in three dimensions (carrier of identity, temporality, and role of the family).

Presas et al. The family firm identity is the basis of the corporate brand and is thus (2011) inherent in the strategic vision, organizational culture, and corporate image.

Zellweger et Family pride, community social ties, and long-term orientation enhance al. (2012)
Quantitative study/US

Quantitative study/Switzerland

Qualitative study/Across continents accept Australia

Case study/Spain

Quantitative study/Switzerland 
Table 2: Firm and interview specifications

\begin{tabular}{|c|c|c|c|c|c|c|c|c|c|c|}
\hline \multirow[t]{2}{*}{ Firm } & \multicolumn{6}{|l|}{ Firm information } & \multicolumn{4}{|c|}{ Interview information } \\
\hline & $\begin{array}{l}\text { Degree of } \\
\text { communication of } \\
\text { Family firm image }\end{array}$ & $\begin{array}{l}\text { Founding } \\
\text { Year } \\
\text { (app.) }\end{array}$ & $\begin{array}{l}\text { Gene- } \\
\text { ration }\end{array}$ & $\begin{array}{l}\text { No. of } \\
\text { employees } \\
\text { (app.) }\end{array}$ & Sector & Industry & $\begin{array}{l}\text { No. of } \\
\text { interviews }\end{array}$ & $\begin{array}{l}\text { Intergenerati } \\
\text { onal } \\
\text { position }\end{array}$ & $\begin{array}{l}\text { Current } \\
\text { role }\end{array}$ & $\begin{array}{l}\text { Duration } \\
\text { (minutes) }\end{array}$ \\
\hline $\mathbf{P 1}$ & $\begin{array}{l}\text { High (family } \\
\text { preservation) }\end{array}$ & 1850 & 6 & 50 & $\begin{array}{l}\text { B2C/ } \\
\text { B2B }\end{array}$ & Liquors & 1 & Incumbent & CEO & $43: 28$ \\
\hline $\mathbf{P 2}$ & $\begin{array}{l}\text { High (family } \\
\text { preservation) }\end{array}$ & 1950 & 3 & 70 & $\mathrm{~B} 2 \mathrm{C}$ & Bakery products & 1 & Predecessor & $\begin{array}{l}\text { Former } \\
\text { CEO }\end{array}$ & $67: 51$ \\
\hline E1 & $\begin{array}{l}\text { Medium (family } \\
\text { enrichment) }\end{array}$ & 1820 & 5 & 40 & $\begin{array}{l}\mathrm{B} 2 \mathrm{C} / \\
\mathrm{B} 2 \mathrm{~B}\end{array}$ & Winery & 2 & $\begin{array}{l}\text { Incumbent and } \\
\text { successor }\end{array}$ & $\begin{array}{l}\text { CEO and } \\
\text { TMM }\end{array}$ & $\begin{array}{l}65: 28 / \\
53: 46\end{array}$ \\
\hline E2 & $\begin{array}{l}\text { Medium (family } \\
\text { enrichment) }\end{array}$ & 1840 & 6 & 500 & $\begin{array}{l}\mathrm{B} 2 \mathrm{C} / \\
\mathrm{B} 2 \mathrm{~B}\end{array}$ & Snacks & 1 & Incumbent & CEO & $73: 23$ \\
\hline $\mathbf{E 3}$ & $\begin{array}{l}\text { Medium (family } \\
\text { enrichment) }\end{array}$ & 1910 & 3 & 80 & $\begin{array}{l}\mathrm{B} 2 \mathrm{C} / \\
\mathrm{B} 2 \mathrm{~B}\end{array}$ & Jams and Jellies & 1 & Incumbent & CEO & $76: 50$ \\
\hline $\mathbf{E 4}$ & $\begin{array}{l}\text { Medium (family } \\
\text { enrichment) }\end{array}$ & 1920 & 3 & 250 & $\mathrm{~B} 2 \mathrm{C}$ & Health care & 1 & Incumbent & TMT & $63: 37$ \\
\hline S1 & $\begin{array}{l}\text { Low (family } \\
\text { subordination) }\end{array}$ & 1530 & 14 & 2,300 & B2B & $\begin{array}{l}\text { Glass } \\
\text { manufacturing }\end{array}$ & 2 & $\begin{array}{l}\text { Incumbent and } \\
\text { successor }\end{array}$ & $\begin{array}{l}\text { CEO and } \\
\text { TMM }\end{array}$ & $\begin{array}{l}29: 57 / \\
42: 51\end{array}$ \\
\hline $\mathbf{S 2}$ & $\begin{array}{l}\text { Low (family } \\
\text { subordination) }\end{array}$ & 1925 & 3 & 800 & B2B & Prosthetic dentistry & 2 & $\begin{array}{l}\text { Incumbent and } \\
\text { successor }\end{array}$ & $\begin{array}{l}\text { CEO and } \\
\text { TMM }\end{array}$ & $91: 20$ \\
\hline
\end{tabular}

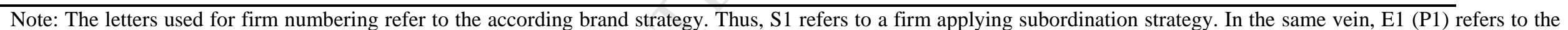

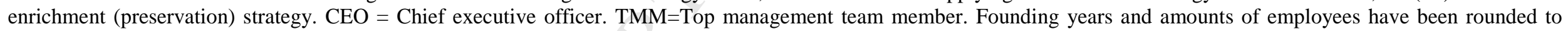
allow for anonymity of the interviewed companies. 
Table 3: Summary of hypotheses derived from study 1

\begin{tabular}{ll}
\hline $\begin{array}{l}\text { Antecedent } \\
\text { (hypothesized } \\
\text { relation) }\end{array}$ & Hypothesis \\
\hline $\begin{array}{l}\text { Innovation } \\
\text { intensity (-) }\end{array}$ & $\begin{array}{l}\text { 1a: The higher the } \\
\text { innovation intensity of an } \\
\text { industry, the less a family } \\
\text { firm communicates a family } \\
\text { firm image. }\end{array}$
\end{tabular}

\section{Exemplary statements}

Firm S2: The slogan [of another exemplary company] implicates (...), that the quality used to be much better in the past. (...) These are industries (...), in which one can leverage the family album. (...) But this is a different form of communication.

Firm P2: But where are nowadays products that are older than 20, 25, or even 30 years? (...) You can search a long time for them.

$\begin{array}{ll}\text { Family firms } & \text { 1b: The more family firms } \\ \text { as } & \text { among its competitors, the } \\ \text { competitors } & \text { less a family firm } \\ (-) & \begin{array}{l}\text { communicates a family firm } \\ \text { image. }\end{array}\end{array}$

B2B sector (-) 2a: A family firm operating in the B2B sector is less likely to communicate a family firm image (compared to family firms in the $\mathrm{B} 2 \mathrm{C}$ sector).

Firm size (-) 2b: The larger a family firm is, the less it communicates a family firm image.

\section{Degree of internation- alization (-)}

Family firms as business partners (+)

2c: The more a family firm operates internationally, the less it communicates a family firm image.

2d: The more family firms are among its major business partners, the more
Firm S1: I definitely say that the family values stand out, as they set us apart from the others in the branch.

Firm S2: There are several [family firms] in our industry. (...) Hence, it [the family firm image] does not serve as criteria for differentiation.

Firm E3: If you are a family firm, you always have a story to tell and a way to distinguish from your competitors.

Firm S1: But we do not offer the typical end-consumer product.

Firm S2: I believe, that it depends on the sector and the customers, whether it [a company] is (publicly) a family firm. (...) But it [marketing with a personal touch] does not make sense for our products.

Firm E4: The people, employees and patients, have adored her [my mother-in-law].

Firm S2: Well, our jubilee of 90 years may be celebrated, but does that make sense? This is the typical age of a grandmother being desperate for help.

Firm E3: In the coffee unit, we try to (...) differentiate our business from large coffee roasters. Thus, being a family firm is highly important.

Firm P1: I would not at all consider us as Mittelstand. We are a small business. (...) Rather a family firm. a family firm communicates a family firm image.
Firm: S2: Well, there are actually no companies, that can exclusively concentrate on the German market. (...) Hence, it [the family firm image] does not serve as criteria for differentiation in international business.

Firm E3: It is indeed a family firm [referring to another exemplary company], but actually it is a global player. Hence, there is no differentiation through it [the family firm image].

Firm P1: Nowadays, the topic regionality is highly important and family.

Firm S2: We experience, that our organizational structure facilitates the dealings with classic, small craft businesses compared to huge corporations.

Firm E2: Our suppliers scrutinize, to whom they deliver their goods, they are partially also, let's say, companies with great tradition.

Firm E3: Especially people, who have a family business on their own and sit on the other side of the table, extremely value it [that we are a family firm]. 


\section{Antecedent \\ (hypothesized Hypothesis \\ relation) \\ Exemplary statements}

Probability of 3a: The lower the succession (+) probability of familyinternal succession, the less a family firm communicates a family firm image.

\section{Family influence on marketing (non- directional)}

\section{Tradition orientation} (+)

\section{Innovation orientation} (-)

Extraversion $(+)$ 3b: The influence of family members on marketing affects the degree of communicating a family firm image. 3c: The more the owning family focuses on tradition, the more it communicates a family firm image.
$3 \mathrm{~d}$ : The more the owning family focuses on innovation, the less it communicates a family firm image.

3e: The more extraverted a family CEO is, the more a family firm communicates a family firm image.
Firm E4: The risk of family firms is the probable lack of a family successor so that the firm must be sold leading to a rupture [regarding the brand].

Firm P2: This [brand] is the tradition, the family and the continuity that results from the family. My son, the third generation, and granddaughter are already ready. (...) This is not something to be taken for granted.

Firm S1: I am not involved in the marketing strategy. Our key account managers made up their minds and told me and my fiancée to attend dinners together to bring the family values into the foreground.

Firm S2: Well, we got 90 years old this year. Our marketing department wanted to celebrate this greatly. We were both unsure, to which extent to celebrate it. (...) This is the typical age of a grandmother being desperate for help.

Firm P1: It is important for a down-to-earth and familial brand, that the wishes and ideas of the family and owners are incorporated. (...) It can be frustrating for [marketing] employees, when the owner has to set some boundaries.

Firm S1: You have to pay attention, that you do not appear to be dusty, too traditional and outdated.

Firm S2: I love to let the grandfather generation tell stories of the war. But this has nothing to do in the professional context. It does not get you anywhere.

Firm E1: Yes, we draw upon tradition and use it in symbiosis with technology.

Firm E3: Following the tradition, the majority of fruits, that E3 manufactures, are even today grown and harvested here in [this region].

Firm E4: We have always been proud and aware of embodying a tradition and we want the name [to communicate the family name].

Firm S1: For instance, on our business cards, you can find the "family [family firm] since XY" and a QR code with all information of the card. We designed it on purpose like this to communicate the long-standing tradition as well as something modern.

Firm E1: It [our innovative approach] is definitely at the expense of traditional values. (...) I don't like this dissociation [of family firm and innovativeness].

Firm P2: We have to pay attention [with our brand] not to be perceived being too far in advance of the times.

Firm S2: We are not the ones, who promote in video clips: „These are my teeth and for them I stand with my name”. We don't do that. I am not that kind of person.

Firm E2: Of course, you don't hide away as entrepreneur. (...) But it is not as if I were an active brand ambassador. That is not me.

Firm E4: We have to become well-known [as a family] and leave a mark in the press.

Firm P2: They interviewed me for two hours, whereof they showed 15 minutes on TV. They also interviewed my son, which was great. (...) I received so many calls. 
Table 4: Sample of the quantitative study 2

\begin{tabular}{lllll}
\hline Characteristic & Min & Max & Mean & SD \\
\hline Founding year & 1830 & 2005 & 1962 & 38.174 \\
Generational stage & 1 & $>4$ & N/A & N/A \\
Number of employees & 10 & 1625 & 113.6 & 196.062 \\
FM in company & 0 & 8 & 2.7 & 1.688 \\
FM as board members & 1 & 6 & 1.8 & 0.973 \\
\% of family ownership & 50 & 100 & 99.5 & 13.883 \\
\hline
\end{tabular}

$\mathrm{N}=196$; Note: $\mathrm{FM}=$ family members

Table 5: Results of PLS-SEM model

\begin{tabular}{llllll}
\hline $\begin{array}{l}\text { Variable } \\
\text { Group }\end{array}$ & Path & $\begin{array}{c}\text { Std. path } \\
\text { coefficient }\end{array}$ & $\begin{array}{c}\text { Std. } \\
\text { deviation }\end{array}$ & $\begin{array}{c}\text { t- } \\
\text { Statistics }\end{array}$ & p-value \\
\hline Hypothesized & H1a: Innovation Intensity $\rightarrow$ FFI & $-0.105^{*}$ & 0.065 & 1.611 & 0.054 \\
antecedents: & H1b: FFs as competitors $\rightarrow$ FFI & 0.040 & 0.062 & 0.652 & 0.257 \\
\cline { 2 - 6 } Environment & H2a: B2B Sector $\rightarrow$ FFI & $-0.082^{*}$ & 0.064 & 1.283 & 0.100 \\
$($ H1a, b) & H2b: Firm size $\rightarrow$ FFI & $-0.073^{*}$ & 0.045 & 1.622 & 0.053 \\
& H2c: Internationalization $\rightarrow$ FFI & $-0.127^{* * *}$ & 0.053 & 2.392 & 0.009 \\
Business & H2d: FFs as business partners $\rightarrow$ FFI & $0.140^{* *}$ & 0.066 & 2.132 & 0.017 \\
\cline { 2 - 6 }$($ H3a-d) & H3a: Prob. family succession $\rightarrow$ FFI & 0.082 & 0.072 & 1.141 & 0.127 \\
Family & H3b: FI on marketing $\rightarrow$ FFI & -0.028 & 0.062 & 0.450 & 0.653 \\
$($ H3a-e) & H3c: Tradition orientation $\rightarrow$ FFI & $0.247^{* * *}$ & 0.060 & 4.088 & 0.000 \\
& H3d: Innovation orientation $\rightarrow$ FFI & 0.020 & 0.067 & 0.291 & 0.386 \\
\hline Performance & H3e: Extraversion family CEO $\rightarrow$ FFI & $0.158^{* *}$ & 0.069 & 2.276 & 0.012 \\
measures & FFI Firm performance & $0.161^{* * *}$ & 0.053 & 3.066 & 0.001 \\
\hline Controls & FFI $\rightarrow$ Brand performance & $0.202^{* * *}$ & 0.085 & 2.372 & 0.009 \\
& Generational stage $\rightarrow$ FFI & -0.142 & 0.146 & 0.977 & 0.329 \\
& Founding year $\rightarrow$ FFI & $-0.280^{* * *}$ & 0.069 & 4.038 & 0.000 \\
& Family ownership $\rightarrow$ FFI & -0.022 & 0.162 & 0.138 & 0.890 \\
& FM as board members $\rightarrow$ FFI & $0.148^{* * *}$ & 0.069 & 2.124 & 0.034 \\
& FM in company $\rightarrow$ FFI & 0.027 & 0.071 & 0.387 & 0.699 \\
& Data assessment type $\rightarrow$ FFI & 0.138 & 0.158 & 0.876 & 0.381 \\
& Influence of branding agency $\rightarrow$ FFI & -0.002 & 0.065 & 0.030 & 0.976 \\
\hline
\end{tabular}

Note: FFI = family firm image (scale from Memili et al., 2010); Firm size = number of employees, FF=family firm, FI=family influence; FM=family member; $\mathrm{p}$-value is one-sided for directional hypotheses and two-sided for undirected hypotheses and controls; t-statistics are derived from a bootstrapping procedure with 2,000 subsamples; Significance levels: $*=p<.10 ; * *=p<.05 ; * * *=p<.01$ 
Figure 1: Overview of two subsequent studies (exploratory sequential mixed methods design)

What are the antecedents of the managerial decision regarding the degree to which a family firm image is communicated?

\begin{tabular}{|c|c|c|c|}
\hline & $\begin{array}{c}\text { Study } 1 \\
\text { (qualitative) }\end{array}$ & $\begin{array}{c}\text { Study } 2 \\
\text { (quantitative) }\end{array}$ & \\
\hline Approach & $\begin{array}{c}\text { Exploratory } \\
\text { (expert interviews and literature) }\end{array}$ & $\begin{array}{l}\text { Explanatory } \\
\text { (survey data) }\end{array}$ & $\begin{array}{l}\text { Exploratory (survey } \\
+ \text { secondary data) }\end{array}$ \\
\hline Aim & Development of hypotheses & Testing of hypotheses of Study 1 & $\begin{array}{l}\text { Explore performance } \\
\text { consequences }\end{array}$ \\
\hline $\begin{array}{r}\text { Dependent } \\
\text { Variable }\end{array}$ & $\begin{array}{c}\text { Family Firm Image: The degree to } \\
\text { which a family firm image is } \\
\text { communicated } \\
\text { (3 degrees, Micelotta \& Raynard, 2011) }\end{array}$ & $\begin{array}{c}\text { Family Firm Image: The degree to } \\
\text { which a family firm image is } \\
\text { communicated } \\
\text { (Continuous measure, Memili et al., 2010) }\end{array}$ & $\begin{array}{l}\text { Subjective brand } \\
\text { performance and } \\
\text { objective sales data }\end{array}$ \\
\hline
\end{tabular}


Figure 2: Overview of the data structure (analysis procedure adapted from Kotlar and De Massis, 2013)

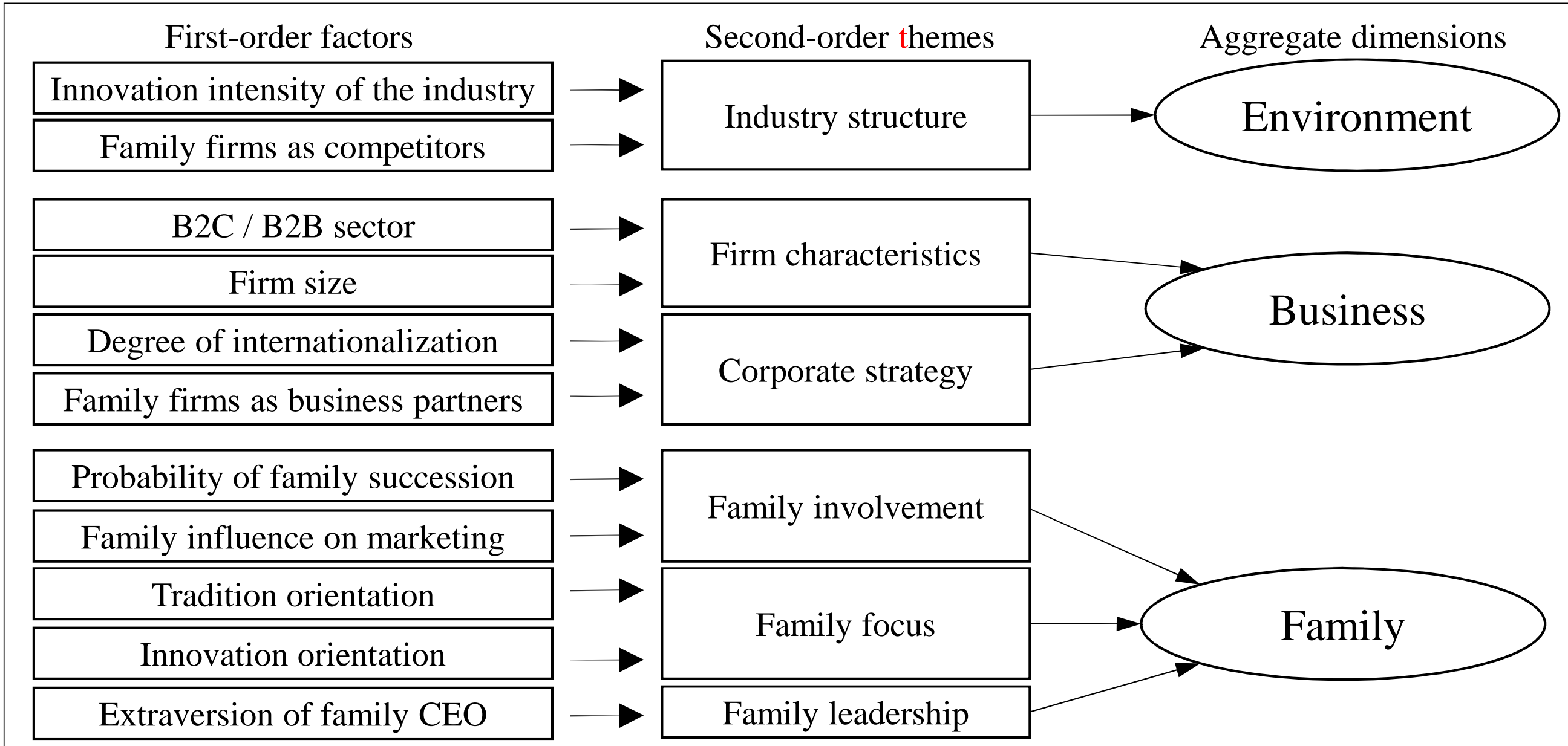


Figure 4: Results of study 2

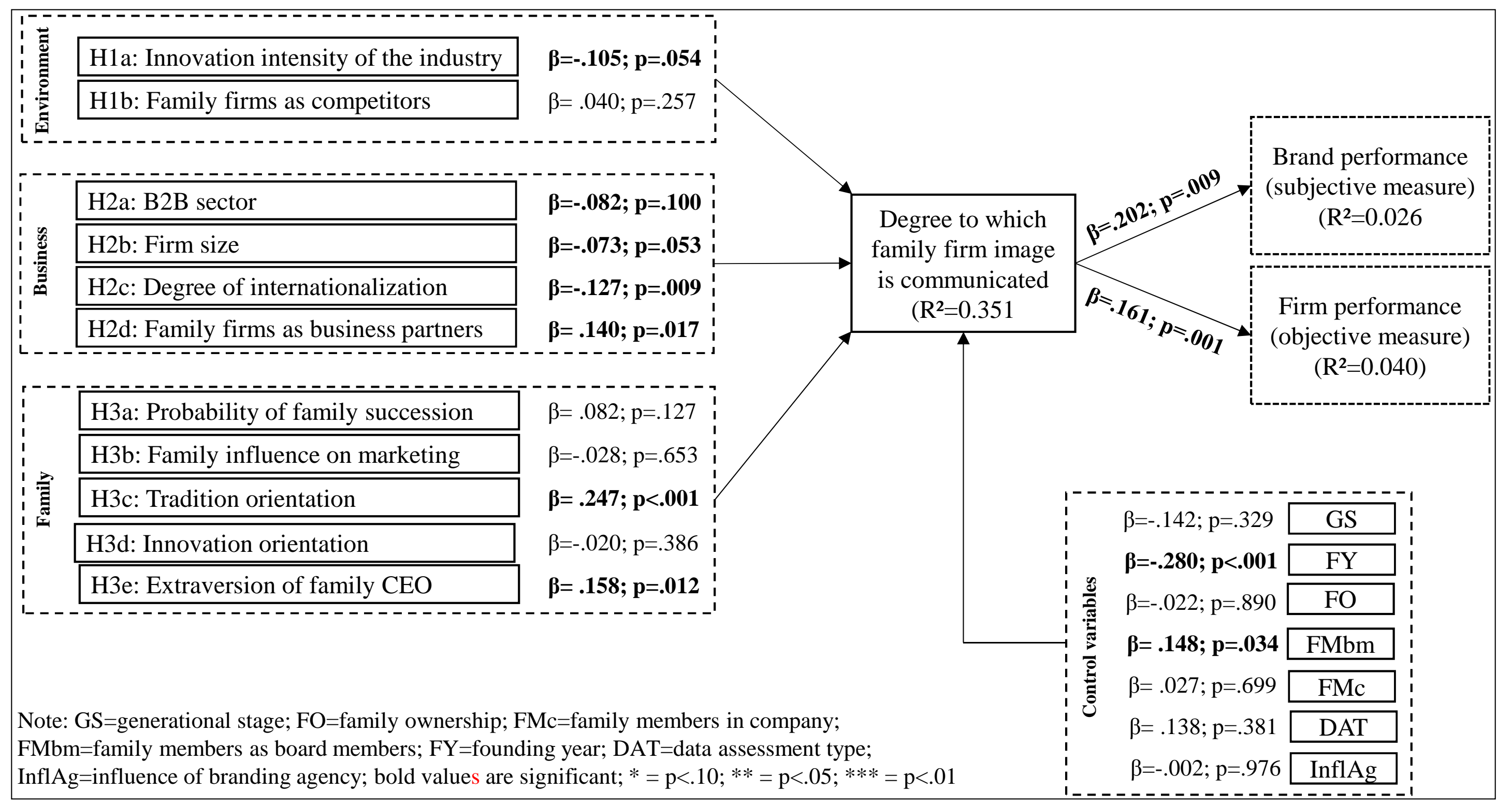

